\title{
Effects of Industry 4.0 on vocational education and training
}



http://epub.oeaw.ac.at/ita/ita-manuscript/ita_15_04.pdf

November/2015

ITA-15-04

\title{
Effects of Industry 4.0 on vocational education and training
}

\author{
Sabine Pfeiffer \\ University of Hohenheim
}

\section{Keywords}

Industry 4.0, Industrial Internet, manufacturing work, initial vocational education and training, continuing vocational education and training, qualification, dual system, participation

\section{Summary}

The paper is concerned with new competencies and qualification in the context of Industry 4.0 (also addressed as the Industrial Internet). The introductory section will outline the state of research and highlight the deficits in the existing data. Although Industry 4.0 also affects many service and logistics sectors, the study concentrates on changes in the core areas of industrial manufacturing work, and focuses on the system of dual vocational education and training, as this has a high, almost unique significance in Germany and Austria. Beginning with development scenarios that are currently under discussion, and with the innovative capacity of the dual system, the paper outlines specific competency and qualification requirements in relation to four qualification-relevant dimensions of Industry 4.0, and, lastly, uses these to make recommendations for policymakers, companies and social partners. 


\section{MASTHEAD}

Media owner:

Austrian Academy of Sciences (ÖAW)

Legal person under public law (BGBI 569/1921 idF BGBI I 130/2003)

Dr. Ignaz Seipel-Platz 2, A-1010 Vienna

Editor:

Institute of Technology Assessment (ITA)

Strohgasse 45/5, A-1030 Vienna

www.oeaw.ac.at/ita

ITA manu:scripts appear at irregular intervals and publish working papers and talks from staff members as well as guests. ITA manu:scripts are exclusively made available to the public via the Internet portal "epub.oeaw":

http://epub.oeaw.ac.at/ita/ita-manuscript

ITA-manu:script No.: ITA-15-04 (November/2015)

ISSN-online: 1818-6556

http://epub.oeaw.ac.at/ita/ita-manuscript/ita_15_04.pdf

C 2015 ITA - All rights reserved 


\section{Table of Contents}

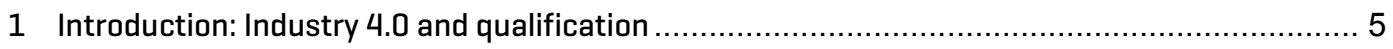

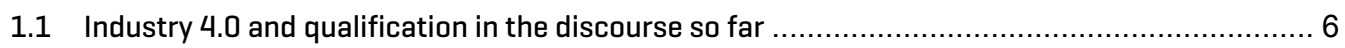

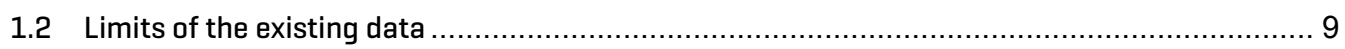

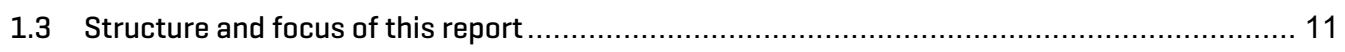

2 Influences and frameworks: options and limitations ............................................. 13

3 On the innovative relevance and innovative capacity of the dual system ............................. 16

3.1 The dual system as a vital medium of innovation ........................................................ 16

3.2 The dual system allows innovative forms of organization ............................................ 17

3.3 Complex economies need diverse pathways to vocational qualification ............................ 18

3.4 Academic and vocational qualification are not opposites ............................................ 18

3.5 Experience is relevant to innovation - even for those with academic qualifications .............. 19

4 From a deficit-oriented to a resource-oriented perspective .............................................. 20

4.1 On the limitations of the routine-based approach .................................................... 21

4.2 Labouring capacity: ensuring successful management of complexity and change ................ 22

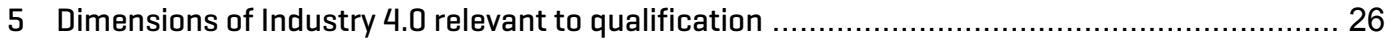

5.1 social media@production: mobile web communication in production ................................ 27

5.2 data@production: the integration of material production ........................................... 28

5.3 nextGEN production: new production techniques ...................................................... 29

5.4 automation@ body \& mind - data-supported access to bodies and knowledge.................... 30

6 Qualification needs and target groups in terms of the Industry 4.0 dimensions.................... 31

6.1 social media@production: comparatively unproblematic ................................................ 32

6.2 data@production: the integration of material production ............................................. 33

6.3 nextGEN production: new content, different players, unrecognized opportunities ................. 34

6.4 automation@ body \& mind - data-supported access to bodies and knowledge.................... 36

6.5 Transversal competences, new forms of learning, new target groups ............................... 36

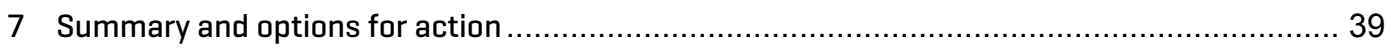

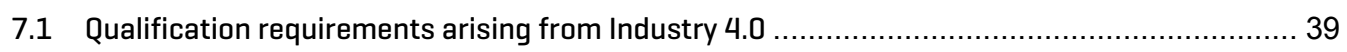

7.2 Transversal competence requirements as part of modern professionalism need the duality of learning venues.......................................... 40

7.3 Recognizing and utilizing living labouring capacity as a resource for the development of Industry 4.0, and creating the conditions for participation ................ 40

7.4 Making skilled labour and the dual system of initial and continuing

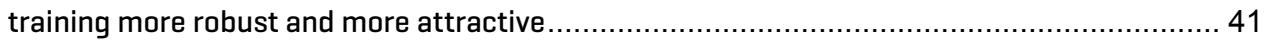

7.5 Creating the conditions that make change possible .............................................. 43

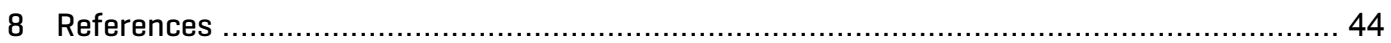

This paper came about as an in-depth study of a selected field of activity, within the pilot project "Industry 4.0: Foresight \& Technology Assessment on the social dimension of the next industrial revolution", a joint research project of the Institute of Technology Assessment of the Austrian Academy of Sciences and the Austrian Institute of Technology, funded by the Parliamentary Administration of the Austrian Parliament. 



\section{Introduction: Industry 4.0 and qualification}

Industry 4.0 (also addressed as the Industrial Internet) is a systemic change, bringing about extensive changes to the world of work. This is not about the introduction of one new technology, linked with an incremental adaptation of work systems, but about a multitude of new technologies and forms of application, with different degrees of technical maturity and systemic effects. With Industry 4.0, steps towards automation proceed more disruptively and with greater risk (acatech, 2015; Bauernhansl et al., 2014), and the spectrum of social challenges is correspondingly wide (cf. Hirsch-Kreinsen et al., 2015). Industry 4.0 thus presents a qualitatively new challenge, even for companies who have had decades of experience with the introduction of new automation technology. The challenge is to devise competitive Industry 4.0 solutions and provide good jobs in production and engineering - i.e. jobs that are skilled, promote learning, and preserve health. In the light of such a fundamental change, it remains to be seen what sort of training and qualifications are required if the aim really is to focus on human wellbeing (cf. Kagermann et al., 2013).

In recent years, the world we live and work in has changed considerably. Computerization has been followed, since 2010, by a strong push towards digitalization, with mobile devices and cloud services making work largely independent of time and place. This increased digitalization of work and business processes not only lends greater importance to web-based and mobile applications, and services based on intelligent analyses of large volumes of data (big data, intelligent algorithms). The scenarios of Industry 4.0 and new approaches in robotics also lead to expectations of major, potentially disruptive changes. On the basis of previous developments, we can work on the assumption of contradictory effects: the opportunities and risks are not far apart. Previous forms of regulation and organization are in some cases no longer effective; new processes and mechanisms are as yet only faintly discernible.

The digitalization of work is not just something that lies ahead; it has already changed work more and more over the last few years, e.g. making it more mobile. This is shown by a current analysis of the most recent mass data on the situation of the working population in Germany (Klein et al., 2015). The analysis is based on the BIBB/BAuA Employment Survey of the Working Population on Qualification and Working Conditions in Germany 2012 by the German Federal Institute for Vocational Education and Training (BIBB) and the German Federal Institute for Occupational Safety and Health (BAuA), hereafter referred to as the BIBB/BAuA survey (year of survey 2012; $n=20,036$ ), the 'Good Work Index' of the German Confederation of Trade Unions (DGB) (years of survey 2012 to 2014; $n$ for each year $=4000$ ), the workforce survey of the Industrial Union of Metalworkers (IG Metall) (year of survey 2013; $n=514,134$ ), the report on absences by the AOK health insurance fund, and various data from Germany's Federal Statistical Office. Taking the example of the automotive industry, we have been able to use four organizational coordinates to trace processes of change - closely linked with the digitalization of work - in recent years. The first observation to be made about the use of information and communication technology (ICT) is that traditional forms of ICT use (computer, email, enterprise resource planning (ERP) systems) are widely established in the big companies, and are part of everyday working life for most employees. In the existing data that has been analysed here, respondents are not explicitly asked about forms of digitalization which play a key role in the production area (such as embedded systems, computer numerical control (CNC) systems, programmable logic controllers (PLCs), bus systems etc.) - for criticism of this see Pfeiffer/ Suphan, 2015). It can therefore be assumed that digitalization in the manufacturing sector is more diverse, more widespread and thus generally more extensive than most statistics are able to show. 
From the analyses of the data sets mentioned above, two statements are of particular importance for the connection between digitalization and qualification in the manufacturing sector:

- For the sphere of education (Klein et al., 2015: pp. 61ff.), a high proportion of practical vocational qualifications can be observed. When it comes to continuing education and training, a contradictory picture emerges: professional development programmes on occupation-specific subject knowledge are a high priority for employees; on the other hand, little use tends to be made of courses on ICT. The data give no conclusive indications of why this is the case. The high degree of digitalization of the industry and the dominance of vocational qualifications suggests that the necessary ICT skills have so far been successfully managed on this level. This does not mean, however, that this will remain so in future.

- For the automotive industry, used as an example in this study, the data analysed also show that the workplace changes workers have experienced and have had to cope with in recent years have been huge, and have been strongly linked with digitalization: within the space of just two years, considerably more than half of employees have been confronted not only with new computer programmes, but also with new manufacturing or process technologies, and new machines or equipment, which generally also come with new control systems (Klein et al., 2015: pp. 75ff.)

\subsection{Industry 4.0 and qualification in the discourse so far}

Typical of the diverse and interest-led discourse around Industry 4.0 (cf. Pfeiffer, 2015a) is the lack of clarity and specificity in the statements made about possible qualification needs resulting from Industry 4.0. In particular, estimations of the importance of skilled labour - and the monetary recognition it deserves - are often very contradictory, from the point of view of consulting firms: for example, Deloitte (2010) sees "talent-driven innovation" as the most important driver in global manufacturing competition, followed, in second place, by the costs of labour. Skilled labour is thus regarded as crucial, but at the same time it is expected to cost as little as possible.

The importance of qualification and skills development for the introduction of Industry 4.0 is according to a study by Fraunhofer IAO - assessed as consistently high. Qualities most often seen as necessary are the willingness to engage in life-long learning ( 86 per cent), more intensive interdisciplinary thinking and action (77 per cent), and a higher level of IT skills (76 per cent) (Schlund et al., 2014: pp. 6-7). So far, discussions of qualification and Industry 4.0 have always involved rather general statements of this kind, focusing on the one hand on soft skills and social competencies, and on the other hand on non-specific IT skills.

Within the debate, there is a general consensus that requirements are increasing, due to the "convergence between mechanical electronic software-based components or systems (...) occurring across scale levels (macro/meso/micro)", and that it will become necessary to deal more with robotics (Hartmann/Bovenschulte, 2013: pp. 33-34). Even the implementation recommendations of Plattform Industrie 4.0, a project instigated by German trade associations, are strikingly vague in their description of the qualification requirements that will arise: there is talk of "much higher requirements for complexity, abstraction and problem-solving", and of a very high degree of "self-directed action, communicative skills, and capacity for self-organization". In other words, it is mainly the "subjective abilities and potential of the employees [that are] increasingly in demand" (Kagermann et al., 2013: p. 57). Plattform Industrie 4.0 also advocates greater integration of ICT, production and automation technology, and software for vo- 
cational education and training (ibid., p. 59) - a demand that had actually become a reality for vocational education and training before the beginning of the debate over Industry 4.0, when 'production technologist' (Produktionstechnologe) became an officially recognized occupational profile in 2008 (cf. Müller, 2012).

Another consulting firm (Blanchet et al., 2014: pp. 12-13) offers the assessment that industrial production is gaining strategic and economic importance, but that production-related qualifications do not seem to play a major role here. According to this view, production is experiencing a "shift toward design thinking instead of production thinking", and the demand for interdisciplinary thinking and the willingness to engage in life-long and intercultural learning are becoming more crucial. The same report states that technical skills are also becoming more "T-shaped and interdisciplinary than specialized", and that engineers and computer scientists are increasingly faced with the challenge of thinking "across business models, production processes, machine technology and data-related procedures" (ibid.). It seems - the study leaves this open that the actual work of manufacturing no longer takes place here, or that there is no need to give any further thought to the training or skills which this work might require.

Others see humans as playing a largely strategic role: "In an Industry 4.0 [context], employees will determine the overall production strategy, monitor the implementation of this strategy, and if need be, intervene in the cyber-physical production system (CPPS)" (Gorecky, 2014: p. 527). According to the same author, however, humans will take on the role of creative problem solvers "if it is necessary to remedy an existing fault or to develop implicit potential for optimization" (ibid. p. 256). This requires, according to Gorecky, "knowledge about the methods and technologies (e.g. knowing how TCP/IP works) that are essential for the implementation of cyber-physical production systems (CPPSs)" (ibid.: p. 527). Where people are supposed to get the qualifications they need if, alongside "planning/creative activities ('mental work' or 'brainwork')", they are to use their skills to "intervene in the processes on the ground ('manual labour'), for example to replace a defective piece of equipment" (ibid. p. 527) - remains open, or is simply taken as a given. Lüder (2014) is somewhat more specific, though only for the engineering level, not for the skilled labour level. He identifies the following new requirements in the context of Industry 4.0: the ability to compile and adapt libraries (of artefacts), to deal with virtual tools for plant design, and to carry out interdisciplinary work in the design process.

Picot and Neuburger (2014: pp. 9-10) name a whole cluster of technical and social skills, but largely assume that only communicative aspects are unable to be automated, and that so far, most of the work done by those at the intermediate qualification level involves following instructions (for a critical account of these basic assumptions, see Pfeiffer/Suphan, 2015b and ch. 4). These authors list, on the one hand, mainly IT-related skills such as the "technical ability to deal with digital media, and the capacity to use these media rationally and efficiently in work processes", abilities in the STEM subjects (science, technology, engineering, and mathematics), software skills in the area of virtual modelling, knowledge about the production process and how it has been changed by digitalization, the capacity to deal with information complexity and data management. But soft skills such as self-management and self-organization, communicative, interactive and problem-solving abilities, project management and "the ability to perceive complex matters in visual terms" are also important (ibid.). 
Often, then, commentators predict an increase in abilities which could be covered by the terms "monitoring/controlling, measuring/testing, organizing/planning". Here they overlook the fact that most skilled occupations had seen a movement towards such job requirements since the 1990s. This has for example been demonstrated for the occupation of fitter (Schlosser), on the basis of changes in the work activities described over several waves of the BiBB/BAuA survey (Tiemann, 2014: pp. 151-152).

A systematic overview of the current state of the debate about qualification and Industry 4.0 has recently been given by Ahrens and Spöttl (2015: pp. 196-200). Taking their lead from Weiland (2013), they generate the following five parameters for the demands arising from Industry 4.0 for the qualification of skilled workers (ibid.: p. 198):

- "comprehensive integration and information transparency,

- increasing automation of production systems,

- self-management and decision-making by objects,

- digital communication and interactive management functions,

- flexibilization of the use of staff."

Weiland assumes that "the degree of specialization of the organization of work in Industry 4.0 can be kept low", but that the distinction between direct and indirect positions is still necessary (2013: p. 65). These assessments should be considered with a degree of caution, however. Elsewhere, the author stresses the fact that "direct positions no longer only involve physical activities, but are becoming more demanding due to decision-making responsibilities and a large spectrum of technical activities" (ibid.). This is an astonishing statement, given that - at the skilled worker level - the importance of physical activities has long since given way to what is referred to as supervising work Gewährleistungsarbeit, i.e. the work done to ensure that effective production can happen (rather than the production itself). Thus the picture of current qualification requirements does not seem coherent here. For the future, the author uses a Delphi survey to reach the conclusion that "The qualification requirements differ with respect to direct and indirect positions. Fundamental functional and extra-functional qualifications are high-level IT skills, a willingness to learn and cooperate, flexibility and personal responsibility, a holistic perspective and a willingness to make decisions (Weiland, 2013: p. 81). Ahrens and Spöttl also criticize Weiland's description, arguing that it overlooks "very specific challenges related to the individual [above-mentioned] parameters", and that it instead discusses "the need for qualifications on the level of an overview" (2015: p. 198). Ahrens and Spöttl are among the very small number of commentators who show a connection between the qualification requirements arising from Industry 4.0 and existing occupational profiles. They thus come to the conclusion that "dimensions of qualification such as the ability to work in a team, reliability, mobility, precision, the ability to negotiate, the willingness to learn, the willingness to cooperate" have been a "fixed component of metalworking and electronics occupations since the restructuring [of the Ausbildungsberufe or training occupations] of 2003 and 2004".

According to Ahrens and Spöttl, only a very small number of qualification requirements are to be regarded as genuinely new and specific to Industry 4.0. They mention the following (ibid.):

- "general understanding of machine interactions,

- general interdisciplinary knowledge of methods,

- fundamental statistical knowledge (data analysis and interpretation)" (Ahrens/Spöttl, 2015: p. 198). 
Very few studies have attempted to break through the predominant focus on social and generic competencies in the debate about qualification in Industry 4.0. One such study deals with the effects of increasing digitalization in various areas of logistics. One of its conclusions, regarding intralogistics in car manufacturing, is that while "the demands imposed on the more highly skilled activities (engineers, master craftsmen) are growing", fewer qualification requirements are necessary on the operative level, and operation of the information technology used "hardly [requires] any training period" (Windelband et al., 2010: p. 42).

Overall, it can be said that the debate that has taken place so far on the qualification requirements posed by Industry 4.0 is still in its infancy. Most of the requirements mentioned address social and generic competencies, coupled with a largely unspecific demand for "more" IT skills, in some cases extending to a generalized appeal to the programming and modelling abilities of all skilled workers. The debate contains virtually no explicit references to specific activities, workplaces or levels of qualification. So far there has also been a lack of sector-specific observations, and of the necessary differentiation into initial training and continuing development, and into academic and vocational routes in education and training. With very few exceptions, no reference is made to existing curricula and occupational profiles, and no attempt is made to link their current content with the presumed future requirements. The present short study cannot compensate for this ongoing deficit; we can only conclude this brief résumé of the state of research with the observation that there is still a great deal to be done.

\subsection{Limits of the existing data}

Before it is possible to usefully estimate future qualification requirements, we need to look at the existing state of knowledge about current developments. As the previous sections have shown, there is no lack of far-reaching visions of the future. If we seek to pin these down, however, it quickly becomes clear that there is a major research deficit - particularly in the area of manufacturing work, but by no means only there. In order to give a well-founded assessment of the changes in our world of work, the first prerequisite would be a detailed knowledge of the current state of affairs. We are still a long way from achieving this knowledge. True, there are a large number of thematically relevant studies, but these are not enough to make serious, sufficiently broad but also detailed statements on the current world of work. And they are not able to adequately encompass the current and expected changes in its complexity, non-simultaneity, and contradictoriness - on which basis specific recommendations for qualification requirements could be made. The deficits in the data are, in brief, as follows:

- Mass data sets collected on a regular basis (e.g. those of the German Institute for Employment Research (IAB) or of the regional and federal statistical offices, but also the BIBB/ BAuA data) do not give a sufficiently detailed representation of newer technical developments and of the specifics of work content, or of company and value structures. Moreover, the survey intervals cannot keep up with the rapid pace of development.

- Qualitative company case studies from different disciplines of labour studies, as well as quantitative surveys of companies or employees, are often narrowly focused on a particular topic or field of research. It is often not possible, in terms of method or system, to relate these to other survey findings. 
- Studies on changes in work within manufacturing have become increasingly rare in recent years, partly as a result of funding structures and themes. Since Michael Schumann's Trendreport (Schumann et al., 1994), there have been no further studies aiming to give a systematic overview of the state of manufacturing work for large industrial sectors.

- Since the 1990s, the theme of technological change as a relevant driver of changes in work has largely disappeared as a topos in labour studies, in favour of a focus on subjects and organizations. The earlier debates about justified criticism of technologically deterministic interpretations led to an almost complete renunciation of the systematic exploration of connections between technicization and work. This has meant that since the 1990s the technological developments arising as a result of computerization have largely been researched only in terms of their "end" - for example the blurring of boundaries and subjectification as the expression and consequence of these developments (cf. Pfeiffer, 2010a).

- Many studies are conducted by trade associations or management consultancies and are thus limited to the sphere of their own clientele (e.g. member companies, customers). Thus their informative value is often limited, and the methods are not always transparent. Most importantly, such studies almost always fail to consider the perspective of the employees and the level of actual work.

There are, then, no representative figures that reliably reflect the present state of manufacturing and assembly work: how many people work in highly automated workplaces, how many in hybrid assembly systems, how many monitor robots, how many work in the area of machining? Where has CNC workshop programming become predominant since the 1980s, and why? Where has this not happened? Where, today, is it possible to find seamless data integration across the product life-cycle? Where, today, do we already have close data links between PPC (production planning and control) systems across whole value chains? What typical arrangements of IT connection, production technology processes, batch sizes and product diversity, product complexity, and required and existing qualification can be found in the areas of German industry that are relevant to competition? All of these things are unknowns. And yet all of these things are important if we want to be able to assess, both broadly and in depth, the possible effects of different Industry 4.0 scenarios, and to draw conclusions from these for education and qualification. This short outline shows that we hardly know anything about the empirical connections between work and technicization. And we know still less about the variety of manufacturing work that exists today. There are no research structures that are able to make a systematic connection between qualitatively observed changes within companies, and their broader relevance. Thus it is seldom possible, today, to arrive at data-based findings which are sufficiently industry-specific and robust to provide orientation for (interest-driven) political action. 


\subsection{Structure and focus of this report}

The aim here is - insofar as this is currently possible - to remedy the existing lack of specific statements about future qualification requirements (cf. section 1.1), and the systematic research deficit on the effects of digitalization on work so far (cf. section 1.2). To keep these remarks about qualification as specific as possible, the following discussion focuses on two areas:

- Firstly, this report is deliberately focused on the core areas of industrial manufacturing work. One fact that cannot be dealt with here, but is highly relevant for the assessment of the whole dynamics of change in the workplace, is that the scenarios of Industry 4.0 not only affect manufacturing work or the manufacturing industries in a narrower sense. Rather, the diverse and systemic quality of new integration, and, for example, lower-cost robots, will also change peripheral areas of the industrial sector and other areas of business.

- A second focus is on the system of dual - initial and continuing VET (vocational education and training); academic forms of qualification and the classic continuing education sector will only be touched on in passing. The reason for this focus is that the dual system enjoys a high level of importance in Germany, as in Austria, and holds an almost unique position within global competition. Particularly in the industrial/technical area, the skilled worker level traditionally holds a key position in the qualification structure of employees in the manufacturing industries.

The study is divided into several steps. The first step will be to present the scenarios under discussion: the choice of particular forms of work organization or of criteria for designing humanmachine interfaces creates frameworks which may not actually determine qualification requirements, but nonetheless have a strong influence on them. This second chapter $(\rightarrow$ section 2 ) will also outline factors other than Industry 4.0 which have an influence, as well as evoke the limits of our ability to shape developments.

The third chapter ( $\rightarrow$ section 3 ) concentrates on the largely underestimated contribution made by the dual system of vocational training to the innovative capacity of industries relevant to competition. Here we will also discuss the innovative capacity of the qualification system itself: this focus is of particular importance in the context of Industry 4.0, since the skilled worker level - and thus initial training in the dual system - has so far played a central role in the qualification structure of industrial manufacturing work. Furthermore, in view of the expected disruptive changes, we have to ask to what extent the historically developed system, with its established actors and firmly institutionalized structures, is sufficiently agile and proactive to support the change from the qualification side.

Anyone wishing to speak about future training and qualification needs must also look at the discourse about the effects of Industry 4.0 on employment. After all, questions about re-qualification or de-qualification, and possibly about new qualification content and pathways, will only arise in future for those jobs that survive industry's new options for automation. However, when commentators are assessing which jobs will continue to exist and which will be automated, they often make inadequate assumptions about how routine these jobs are, especially in the manufacturing environment. This often superficial and misleading viewpoint is presented in the fourth section ( $\rightarrow$ section 4 ), and the deficit-oriented view which predominates in labour market research is expanded to include a focus on human labouring capacity as a resource. 
The fifth section $(\rightarrow 5$ ) specifically considers four technical dimensions of Industry 4.0 that are relevant for qualification. These explicitly do not lead to a technologically deterministic view, but are intended to do justice to the diversity and heterogeneity of all the developments that are discussed under the label of Industry 4.0. If one wishes to assess qualification requirements, it makes a difference whether one is talking about an app such as "Doodle" for coordinating shift work, or about additive processes. This differentiation is first described on the basis of concrete use scenarios, then specifically related to qualification requirements and target groups in section $6(\rightarrow 6)$. The final section $(\rightarrow 7)$ then discusses key options for action. 


\section{Influences and frameworks: options and limitations}

Scenarios of cyber-physical systems (CPSs) and the smart factory (Kagermann et al., 2013: pp. 5ff.) are associated with the vision of a "completely new concept of production automation" (Hirsch-Kreinsen, 2014a). What the development means for workers in production has not yet been clearly outlined. Commentators stress that humans will not be "demoted to biological robots" (Bauer et al., 2014: p. 18), and that, at most, repetitive and physically demanding tasks will disappear - to be replaced by creative knowledge-based jobs in production (Neumann, 2014; Spath, 2013: pp. 20ff.). On the other hand, the history of the digitalization of work so far has shown that potential positive effects for work do not automatically materialize, and are not naturally "built in" to the technology, but have to be deliberately created. This is shown by such phenomena as the blurring of boundaries and work intensification, and the standardization of knowledge work, but also the greater ease with which the global division of labour can be arranged.

Overall, the discussion is dominated by diametrically opposed scenarios, each suggesting that only one way or the other is possible, and each distinguishing between a positive and a negative scenario: on the levels of work organization, the division of labour between humans and machines, and effects on employment:

- Thus assessments about work organization in Industry 4.0 mostly vary between two poles: some postulate a polarization between qualified experts on the dispositive level, and simple, semi-skilled activities on the operative level, others a swarm organization, which identifies skilled personnel with high levels of autonomy on both the dispositive and the operative level (Hirsch-Kreinsen, 2014b: pp. 23ff.).

- When it comes to the different scenarios of labour division between humans and machines that are considered in the qualification debate, the concepts discussed as alternatives ultimately follow a similar logic. Here the two opposite views are the tool scenario (expert systems for skilled workers) and the automation scenario (restricting the autonomy of skilled workers) (Windelband/Spöttl, 2012: p. 217).

- Just as diametrically opposite are the assessments of effects on employment. While management consultancies predict an increase in employment in Germany (the Boston Consulting Group, for example, assumes there will be 390,000 additional jobs, Rüßmann et al., 2015), Frey and Osborne (2013) predict that 47 per cent of employees in the USA will face a high risk of rationalization as a result of big data, robotics and intelligent algorithms. With the same methodology, Bowles uses ILO data for Germany to predict that 51 per cent of jobs are at risk of automation (Bowles, 2014). A reduction in employment - or this is the assessment for the automotive industry at least - is seen as unavoidable, even in Germany, but it is argued that the demographic change means it will be possible to manage this in a socially responsible manner (Neumann, 2014).

Such black-and-white oppositions suggest that we are standing at a clearly identifiable crossroads, where it is necessary to choose one pathway or the other, with no room for an alternative. Reality will be more complex, and developments will be contradictory and non-simultaneous. Diametrically opposed scenarios are exaggerations, which, in the discourse about Industry 4.0, help to clarify what developments are desirable on the way to the future of work. However, the decisions that are necessary for this must be actively negotiated (or possibly even fought out), step by laborious step, in the workplace and in society. What Industry 4.0 ends up 
being, whether the process will have earned the name "industrial revolution", whether technological options will be designed in such a way that work and life become better for many, or whether we and the robots will all become indistinguishable elements of a globally linked "blended workforce" (for a critical view of this see Pfeiffer, 2015b) - this lies in all of our hands. It is therefore not productive to simply take the above-mentioned scenarios and extrapolate consequences for vocational education and training. Furthermore, there are other developments which may have a negative impact on the path towards Industry 4.0, making it rough and nearly impassable - or easier and faster. Some of the other factors influencing the development of Industry 4.0 have a mixture of reinforcing and counteractive effects; they are themselves contradictory and complex, and cannot be seriously used to predict the future. Here we will mention only three of these, which could be particularly relevant for the development of Industry 4.0 and the issue of qualification:

- Disruptive changes on the product level: this is most obvious when it comes to electromobility. If forms of use in this area change enough to cause a disruptive increase in electric vehicles, with major cuts in the production of cars with combustion engines, this might have more effects on employment and qualification than Industry 4.0. Decreasing proportions of mechanical elements in mass-produced cars would not only mean changes to production processes in the main manufacturing companies; entire value chains, right to the smallest sub-contractors, would be reconfigured, with huge effects on the supplier industries. The importance of metal machining and forming would change enormously, with unforeseeable effects for employment and qualification.

- Disruptive change on the materials side: while it is mainly IT-driven change that is seen as innovative and relevant to competition in the current discourse, innovations in the area of materials may turn out to have just as much relevance for change. For Industry 4.0, graphene is the material that is likely to play the most important role here. If, in the next decade, scientists succeed in developing additive processes with graphene for everyday industrial use, this could make a large proportion of the currently prevailing manufacturing techniques obsolete, or at least radically change them. Here too, the effects on employment and qualification could be more dramatic than in the scenarios that have so far been discussed in relation to Industry 4.0.

- Changes to the labour supply: some national economies in Europe are suffering from a demographic development associated with a rapid increase in older people in the workplace. This is already resulting in a shortage of skilled workers in some regions and industries, both in the health and care sector and in the STEM fields. On the other hand, we can observe persistently high rates of youth unemployment in southern Europe and, for example, Germany: despite the booming labour market, a frighteningly high proportion of young people are not being integrated into the labour market or into education and training programmes. The young people who have recently arrived or are just arriving on the labour market, the Millennials and Generation Z, seem to have different expectations of work, especially in terms of work-life balance - or at least this is what current studies suggest. For various reasons, companies are no longer able to calculate the supply on the labour market as well as before, and have to develop different strategies in different labour market segments, more than in previous decades. The outcome remains to be seen. At the same time, globalization and digitalization offer companies new opportunities to become even more independent of the local labour supply, be it by means of more extensive offshoring or new models such as crowd working, or the on-demand or sharing economy. 
Finally, in a global and - economically and technically - more and more closely interconnected world, global and social changes are also influential, even those in other parts of the world. In some cases it will be harder to keep these on a national level than it is today. Climate change, new geopolitical conflicts, increasingly extreme social inequality in the developed economies, and the growing importance and vulnerability of global infrastructures - these changes, which historically develop in broad phases, could easily reduce to absurdity all the Industry 4.0 scenarios currently under discussion. Another element of this global perspective is that issues such as qualification and work, which have so far mainly been organized in national contexts, and negotiated by national constellations of actors, will increasingly be structured by global actors and transnational strategies. In particular, information technology and data structures will be determined by the global players from Silicon Valley, and in future, probably more and more by IT companies in Asia. Transnational trade agreements and the related legal situations are explicitly aimed at undermining national regulatory models. In future, anyone wishing to organize work and qualification in a local context will have to bear in mind how our scope to influence things on this level has changed. 


\section{On the innovative relevance and innovative capacity of the dual system}

In the manufacturing sector, the expertise and experiential knowledge of employees trained in the dual system has a special significance, not only culturally and traditionally, but also in a very real sense: it is both relevant for innovation and a decisive factor in competition. This situation must be recognized and taken into account when it comes to assessing future developments. The following section will summarize the relevant state of research, based on the following hypotheses.

\subsection{The dual system as a vital medium of innovation}

Both economic performance indicators and the results of qualitative innovation research show that innovation does not stop at the doors of R\&D departments. It arises in the interplay between a wide range of disciplines and departments, right across the product lifecycle. And here we find not just employees with academic qualifications, but also those trained in the dual system. Thus employees with technical or science-oriented vocational qualifications play a key role in innovation projects, within R\&D departments, as skilled workers in prototype building, in the fields of testing or implementation, as draftsmen and draftswomen in construction, or as laboratory technicians in various specialist areas (Kädtler et al., 2013). This list in itself shows that innovative products increasingly require knowledge from different engineering phases (from development to maintenance), and engineering disciplines (mechanical, electrical, software engineering), which are each used in lifecycles of differing lengths (Li et al., 2012).

In highly innovative mechanical engineering companies, for example, the special role of employees with vocational qualifications for a comprehensive innovation process across the whole product lifecycle is obvious: in the development, production and assembly relevant to a specific order, but also in the areas of sales, process planning, procurement, and service and maintenance (Wühr et al., 2012). Thus companies owe much of their success in innovation to those departments in which the proportion of employees with vocational qualifications is usually much higher than that of employees with academic qualifications. In the automotive industry too, engineers and skilled workers collaborate closely, particularly at the interface between product innovation, production technology, and plant and process design. Here innovative process improvements and related ideas for innovation are often derived from the experiences of the skilled workers (Schulze, 2000). Here a key role is played by toolmaking, and the manual work of the skilled workers in this field (Haasler, 2004). 


\subsection{The dual system allows innovative forms of organization}

Besides product and process innovations, an increasingly crucial factor in competition is innovative, i.e. flexible, participatory and lean forms of organization. It is generally assumed that a higher formal and more academic qualification is a better preparation for working in organizational contexts that allow - but also require - more autonomy. Empirical experience proves, however, that the model of dual vocational training also offers employees, companies and their forms of work organization good preparation for the future. A European comparison of forms of work organization in the manufacturing industry shows not only that learning organizational forms (defined by criteria such as learning requirements, complexity of tasks, or problem-solving activity) are found significantly more often in Germany, but also that there is a clear connection here with the vocational training system (Lorenz/Valeyre, 2005). The more skilled workers with vocational training are found in production, the leaner the management levels can be. This is confirmed by comparisons between the mechanical engineering sector in Germany, Switzerland and Great Britain (Ryan et al., 2011), as well as in France (Harzing/van Ruysseveldt, 2005).

What is interesting, however, is not only the connection between vocational education and training, and more effective and innovative forms of work organization in manufacturing, but also, related to this, the greater capacity of companies to actually tap the potential of new production technology. For example, all the countries compared in the study started to introduce electronically controlled machine tools (CNC machines) in the 1970s, but only Germany succeeded in using the potential of production planning and control by machines in a more targeted way (ibid.: 126). This observation makes it clear how crucial vocational qualification is for innovations, especially in light of the current debates about the implementation of Industry 4.0. Clearly, occupations react not only to changed technical requirements, but also - and it seems this will be at least as important in the future - to changed forms of work organization. Today, vocational training is already socializing its subjects less and less for hierarchical forms of work organization, and more for self-organization and flexible forms of work organization (Bosch, 2014). The ability to master changed forms of organization, and to act quickly and effectively within them, is becoming more and more relevant in a rapidly changing world of work. This requires a complex cluster of informal and habitual abilities, which can be referred to as "organizational labouring capacity". To develop this, a three-year course of vocational training, with the workplace as the learning venue, turns out to be a fruitful environment (Pfeiffer et al., 2014). In order to build up participatory work structures, the development of skills and organization must be connected. Here employees who identify with the product make a vital contribution (Antoni et al., 2013).

The main thing that innovative and ever more dynamically changing worlds of work demand from skilled workers is a calm and confident approach to complexity. How the education and training system can best prepare people for this is currently the subject of heated debate, centred around the concept of academization (Nida-Rümelin, 2014). This is the subject of the next three hypotheses, which criticize the usual distinction between theoretical knowledge and practice-related experiential knowledge, and show that complex economies such as Germany or Austria rely on a variety of different qualification content, venues, and pathways, and will rely on these even more in the future. It is therefore counterproductive to play off academic knowledge against practical experience. Instead it is vital that both pathways, i.e. vocational and university education and training, transmit more meta-knowledge and theoretical knowledge, as well as instilling the capacity to find experience-based and practical solutions. 


\subsection{Complex economies need diverse pathways to vocational qualification}

Recent observations on the complexity of economies have shown that the more different products can be exported, the more complex a national economy is, and the wider its range of non-tradable goods, such as property rights, regulations, infrastructures and specific qualifications of the workforce - in other words, resources that cannot be simply imported or copied by other countries (Hidalgo/Hausmann, 2009). A key indicator of the capabilities of complex economies is the number of job categories that are involved in making a product (ibid.: 10573). Clearly, the degree of differentiation and the high degree of specialization of occupational profiles is a key determinant of the development of complex economies - and is at the same time an effect of this development. Germany leads the worldwide ranking, ahead of Japan and Switzerland: this is, by far, the country producing the most highly complex products. But for this very reason, Germany is placed at the lower end of the scale regarding prospects for the future (Hausmann/Hidalgo, 2014): according to these authors, Germany can only generate new opportunities for growth if existing and emerging capabilities are combined in new ways, allowing the development of completely new products. These calculations by the Massachusetts Institute of Technology (MIT) show that differentiated vocational skills are the consequence and the prerequisite of complex and thus successful economies. Germany is in a particularly strong position here, but can only achieve further successes if existing capabilities - the current diverse range of vocational and academic qualifications - are more systematically utilized.

\subsection{Academic and vocational qualification are not opposites}

A high proportion of those entering the training system, those already working, and also established managers, have achieved qualifications both in the dual system and in academia. Today, employees are already responding to the need to combine different teaching forms, venues, and contents. Commentators often overlook the fact that not only the "purely vocational" and the "purely academic", but also the "vocational-academic" type of education and training has always had a high level of importance in Germany. Between 1984 and 2008, the proportion of managers with only vocational qualifications decreased, and the proportion with only academic qualifications increased. At the same time, however, the proportion of managers with a vocational and an academic qualification has remained relatively constant, at just under 20 per cent, since 1993. Overall, considerably more than half the managers in the German private sector have completed dual vocational training (Franz/Voss-Dahm, 2011). In especially innovative sectors such as mechanical engineering and the automotive industry, this proportion is at its highest, 21 per cent - although this is also the area containing the highest proportion of managers with purely academic qualifications (ibid.).

Many school-leavers seem to have little desire to commit to one pathway or the other at an early stage: in 2012, over half of the young people beginning a vocational training course were entitled to study. Conversely, one fifth of those beginning tertiary study had already completed a course of vocational training. And yet the "third educational pathway" (dritter Bildungsweg), which is intended to make it easier for people with vocational qualifications to embark on further academic qualifications, has not become especially popular so far (BMBF, 2014). It should 
be noted, though, that those entitled to study seldom choose training occupations (Ausbildungsberufe) in the industrial or technical sphere (Ahrens/Spöttl, 2014). If, in future, measures to expand transfer opportunities become more effective, and dual study models combining vocational training and tertiary study become more prevalent, then a clear separation between the vocational and academic pathways to qualification will become even more obsolete. After all, a substantial practical element is increasingly valued within academic training too: in BadenWürttemberg, a quarter of bachelor's degrees at universities of applied sciences are already being offered as dual courses of study (BMBF, 2014).

\subsection{Experience is relevant to innovation - even for those with academic qualifications}

In recent years there has been an increasingly fierce debate about the academization of vocational qualification. One side vehemently demands that experiential knowledge be replaced by "systematic", in other words theoretical and scientific knowledge (Baethge et al., 2007). The other side emphasizes the inherent and social (as well as economic) importance of practical, "propositional" knowledge, such as that of the "good craftsman", "who is not able to explain in words why this is exactly the way a thing should be done", yet in "many cases [...] showing" is enough to convey this knowledge (Nida-Rümelin, 2014: p. 89). A few years earlier, writers such as Sennett (2009) and Crawford (2009) had, like Nida-Rümelin, rightly argued against the longstanding but erroneous opposition between knowing that and knowing how.

Both positions - the demands for greater academization and the calls for a return to a simplistic understanding of craftsmanship - ultimately celebrate a historically outdated image of crafts and trades. This corresponds neither to modern trades, nor to other occupations with a high proportion of manual, physical forms of knowledge and skill - be it occupations in the industrial/ technical sector, or in the social and care sector. Even these occupations have long since - of necessity - been enriched with increased requirements for theoretical and abstract knowledge, both in training and in vocational practice. This applies even to so-called "simple work" (Pfeiffer, 2007). Conversely, there is no question of an "end to experiential knowledge" (Baethge et al. 2007), especially in innovative fields; instead there is an effort to connect theoretical knowledge about production technology and the practical knowledge of skilled workers in production with the knowledge of the development engineers: their theoretical knowledge based on engineering science, and their experiential knowledge based on engineering practice (Pfeiffer, 2010b). This fruitful interaction is endangered if academic training produces only "Moderations-Mechatroniker", i.e. mechatronics engineers whose skills lie in moderating discussions or in "engineering by PowerPoint" - a term used by those in the industry to describe engineering graduates who have too little grounding in industrial practice (Pfeiffer et al. 2012). Skilled workers and engineers need their own specific, but mutually compatible experiential and theoretical knowledge, especially in innovative and technology-driven companies. Here practice-related experience becomes the crucial resource in dealing with unpredictability and complexity (Böhle et al., 2004), and in digitalized worlds of work (Pfeiffer, 2014). 


\section{From a deficit-oriented to a resource-oriented perspective}

The question of qualification cannot be considered without reference to assessments of the employment effects Industry 4.0 is expected to cause. The question of whether certain human activities will cease, or new ones will emerge - and if so, which activities - is of urgent interest to society. And it is obvious that there can be no simple answers to this. One reason is, we are dealing with disruptive technological changes. The other: the outcome of the development is not a consequence that is causally derived from the technology. Nonetheless, we are currently confronted with diametrically opposed prognoses: while some predict 390,000 new jobs for Germany (Rüßmann et al., 2015), others, on the basis of Frey/Osborne's methods (2013), expect Germany to lose over 51 per cent of its jobs (Bowles, 2014).

In each case, the basis for such estimations is the question of whether activities are regarded as routine work, as this is seen as particularly susceptible to automation. In view of the new technological scenarios, activities other than the 'usual suspects' are affected: with driverless cars, or with expert systems based on big data analysed with intelligent algorithms, this could affect not only repetitive, simple industrial or administrative work, but also parcel delivery drivers or specialist doctors - at least according to current estimates (Brynjolfsson/McAfee, 2014; Pistono, 2014). Despite this possible expansion of the potential for technology-induced rationalization of human work, the distinction between routine and non-routine continues to play a leading role in assessments of how many different occupations and activities will be affected. While routine work is regarded as automatable and thus replaceable, interactive or analytical and caring activities, for example, tend to be seen as hard to replace by technology. All the studies of this kind follow a similar procedure: they begin by categorizing individual activities as routine or non-routine, then take this as the basis for calculating the quantitative extent to which different occupations or levels of qualification will be affected. While the second step is purely calculation, the first is anything but trivial: methodologically, it is only viable if a) routine is clearly defined, and b) the classification of individual activities as routine/non-routine can be made clearly, on an empirical basis, and with sufficient accuracy. Only if these assumptions and steps are plausible, valid, and methodologically transparent do they allow assessments of what activities could potentially be affected. This would still need to be distinguished from a prognosis about what actually will be affected - after all, the history of the first three stages of industrialization has taught us that the question of which human activities are replaced (or for example relocated) is decided on the basis of economic criteria and not simply technical feasibility. UItimately, the same will apply to the fourth industrial revolution. 


\subsection{On the limitations of the routine-based approach}

The starting point for all assessments of the employment effects resulting from new waves of digitalization is the distinction between routine and non-routine activities, with routine being regarded as replaceable by technology and non-routine as the sphere of human work activity that cannot (yet) be automated. However fundamental and relevant this distinction is for all further deductions and extrapolations, it is far from clear and unambiguous. In their much-quoted study, Frey and Osborne (2013: p. 30) held a workshop in which they evaluated ("subjectively hand-labelled") 70 activities in terms of their likelihood of automation, giving scores between 1 and 0 . At least they did not do this alone, but with researchers from the field of learning systems. These, however, were not experts on labour, but experts from 'leading edge' technology development. In other words, experts whose déformation professionelle might lead them to systematically underestimate the material specificities and the complexity of work situations. Who these experts were, exactly how the assessment of automatability was undertaken, and what understanding of routine guided this process - none of this is revealed by the study (cf. Pfeiffer/ Suphan, 2015).

For Germany, similar assessments are usually undertaken on the basis of the BIBB/BAuA survey. With a representative sample of over 20,000 respondents, this is the largest regularly conducted activity-based survey in Germany. In recent years a number of studies have used these data to identify connections between technological developments and effects on employment (e.g. Alda, 2013; Antonczyk et al., 2008; Spitz-Oener, 2007). These studies do not usually call on any technology experts, but they too categorize activities as routine or non-routine. This occurs without any theoretical or empirical explanation of the concept of routine, and without showing reasons for the choice of categorization made in each case. Thus it seems that these choices are also based on subjective assessments - perhaps not an adequate basis if it is to be used to make quantitative statements about employment effects resulting from possible technological automation.

Let us consider this using an example especially relevant for the topic of Industry 4.0: work on, with, or in relation to machines. In the latest BIBB/BAuA survey, from 2012, there is only one single activity item in which the word "machine" appears: the question is how often the "monitoring or controlling of machines, equipment, technical processes" occurs in the respondents' own work. The possible answers are "often", "sometimes" or "never" (Rohrbach-Schmidt/Hall, 2013). The above-mentioned studies all agree that work on machines is to be classed as manual, routine activity. This direct equation of work on machines with manual, routine work is a huge over-simplification, as shown by two examples from our own current empirical observations. Both examples are deliberately taken from areas of the automotive industry that are already highly automated: with a degree of automation of well over 90 per cent, they are representative of workplaces already characterized by a high degree of integration, extensive use of robotics, and by IT-supported identification of every product - in other words, workplaces that already demonstrate a high level of readiness for Industry 4.0:

- Example 1: A skilled worker monitors eight production robots, working together in a process sequence within a tightly scheduled serial production - the typical picture of a "robot ballet". If disruptions or stoppages occur, the worker either remedies them himself or - based on his own assessment - summons the relevant specialists from the maintenance department. Even during a normal shift, with no disruptions occurring, he/she intervenes at various different points in the process, to prevent imminent disruptions. For this, the plant operator has to understand a large number of different technical matters both in their individual logic and in their combined effect - including product materials, processes of wear and tear, and 
robot control. His frequent, preventive intervention only becomes visible, even in the operating environment, if it does not occur (enough), that is, if the incipient disruption is not anticipated and avoided by appropriate situational action.

- Example 2: A production line deploys non-stationary robots that move axially. The transverse axes required for this have gear racks that accumulate dirt during the process, and require regular and elaborate cleaning. One team of production workers, self-organized and selfmotivated, seeks a solution. In a project carried out over a number of weeks, the shift team invents a completely wear-free cleaning gearwheel, which ensures constant cleaning while the plant is in operation. This entire innovation is implemented by the team itself - from the idea, over the construction, and the search for a suitable material. The company allows the necessary time resources. After testing, the solution is rolled out to all areas, and the company saves large sums of money from day one.

If the workers from these real examples of everyday manufacturing work in Germany were to take part in the BIBB/BAuA survey, they would probably all, for want of an alternative, give the answer "often" for the item "monitoring or controlling of machines, plants, technical processes". In terms of the categorizations usually used in employment studies, as discussed above, this would mean that their work would be regarded as a routine activity, easily automated and therefore replaceable. According to Frey/Osborne (2013), this work would automatically be counted among the roughly 50 per cent of activities which are likely to fall victim to digitalization in the coming years. These examples show how little the activity-based mass data sets reflect the diversity and complexity of real work on and with machines and equipment, and they make it clear that substantial misinterpretations can arise from a conception of work on machines - and of the degree of routine involved - if this does not have firm empirical foundations. The two examples, as the brief description was intended to show, do not represent dull routine or repetitive work, but, on the contrary, the interlinking of theoretical and experiential knowledge.

\subsection{Labouring capacity: ensuring successful management of complexity and change}

Experience as the 'dynamic sister' of static routine shows its importance most clearly in complex and highly automated or digitalized work environments. This is not a new insight in work and industrial sociology: the role of experience and subjectifying work action in the transition from conventional to computer-controlled machine tools was discovered in the late 1980s (Böhle/Milkau, 1988), and later confirmed for highly automated process chemistry (Bauer et al., 2006) and assembly work (Pfeiffer, 2007). The concept of subjectifying work action sees people as being involved in work with all their senses. Not only reason and logic help them to make the right decisions in critical (or time-sensitive) situations, but also intuition, gut feelings and emotion. These abilities only develop over the course of time, and are therefore mainly found in experienced employees. Theoretical knowledge and routine help people deal with standardized processes and unchanging, recurring requirements. Experience, however, helps to deal with the unforeseen, even under time pressure, and, if necessary, to come up with new ad hoc patterns of action (Böhle et al., 2009). Living labouring capacity (Pfeiffer, 2004) conceives experience not as a static collection of routines, but as a particular way of dealing with things, people and situations. Even in - indeed, especially in - work environments with a high level of digitalization and automation, these qualities of dynamic experiential knowledge play a special role, particularly in complex and confusing work situations, and when dealing with unpredictability (Böhle 
et al., 2004). With increasing automation and digitalization, systems will inevitably become more complex, and the management of disruptions, which has not (yet) been automated or algorithmized, will therefore require more living labouring capacity - not less, as is often assumed - in order to find situational solutions.

Experience, then, needs to be described in far more complex terms, not simply with the categories of routine or non-routine. It is also something that will play a major role on the way to Industry 4.0 scenarios. It is therefore worth supplementing the deficit-led perspective criticized above, on routine and its potential for automation, with a resource-oriented view of experience. Using the BIBB/BAuA survey of 2012, the following section will not consider what jobs we might lose in future due to Industry 4.0, but will ask: do we have, today, sufficient competencies for the development of Industry 4.0? The focus here is not on new formal knowledge requirements, but on the skills that are needed to cope with change and complexity. In order to do this, we have (as described elsewhere: Pfeiffer/Suphan, 2015) transferred the qualities of subjectifying work action and living labouring capacity to items of the BIBB/BAuA data, and displayed these in an index. This labouring capacity index (LC index) covers both situational and structural requirements posed by complexity and unpredictability, and the need for subjectifying work action when dealing with these. The overall index is constructed normatively from 18 items on the basis of the research outlined above, and is made up of three weighted sub-components and a multiplier (for the methodological steps and the calculation of the index see Pfeiffer/Suphan, 2015). Three items reflect situational approaches to complexity, seven form the index component situational unpredictability, seven items generate the index on increasing structural complexity, and one multiplier item stands for the relevance of experiential learning. The closer the calculated index value is to 1 , the more the respondent needs living labouring capacity to deal with situational unpredictability, complexity and change. For 19.7 per cent of the working population, the value of the LC index lies at 0 ; for the remaining 80.3 per cent of respondents, the LC index follows a normal distribution. The vast majority attain an LC index value of over 0.50 : thus over 71 per cent of the working population cope with complexity, unpredictability and change on a daily basis. In the field of mechanical and plant engineering, this figure even rises to 81 per cent. These workers can act situationally, even if not all the information is available. They are able to acquire experience and to apply this whenever complex work situations require it - in short, what they are doing is the opposite of routine.

Table: LC index values for selected occupations of particular relevance for Industry 4.0

\begin{tabular}{lccc} 
Selection of current occupations & $\begin{array}{c}\text { LC index } \\
\text { [mean value] }\end{array}$ & N & sd \\
\hline Electrical occupations & 0.613 & 365 & 0.272 \\
\hline Industrial mechanics/toolmakers & 0.622 & 346 & 0.267 \\
\hline Engineers & 0.673 & 518 & 0.216 \\
\hline Technicians & 0.674 & 680 & 0.214 \\
\hline Core IT occupations & 0.691 & 504 & 0.188
\end{tabular}

LC Labouring capacity ; sd standard deviation 
A look at occupations particularly relevant to Industry 4.0 shows above-average LC index values (see table). This suggests that high requirements of complexity and unpredictability, and subjectifying work action, are already characteristic of most of the occupational areas linked with the Industry 4.0 discourse. The highest score goes to core IT occupations, followed by technicians, engineers, and then the dual metalworking occupations (the table only shows a selection of production-related occupations relevant to Industry 4.0, with a three-digit N). Whether they have a vocational or academic qualification, workers in these areas seem to use their living labouring capacity to a similar extent when dealing with complexity - and this is already the case today. This also applies to an above-average extent to industrial mechanics and toolmakers, i.e. occupational groups which the above-mentioned studies on employment effects classified as pure routine and therefore easily replaced by technology - because they involve work on machines. By comparison, the occupational group "management, management consulting and business consulting" - i.e. a group normally regarded as having particularly high complexity requirements - attains an LC index value of 0.662 . This group therefore lies only slightly ahead of the industrial mechanics and toolmakers. The following graphic shows the mean values and variance for the three levels of qualification: low (no training), medium (vocational training and education) and high (academic qualification).

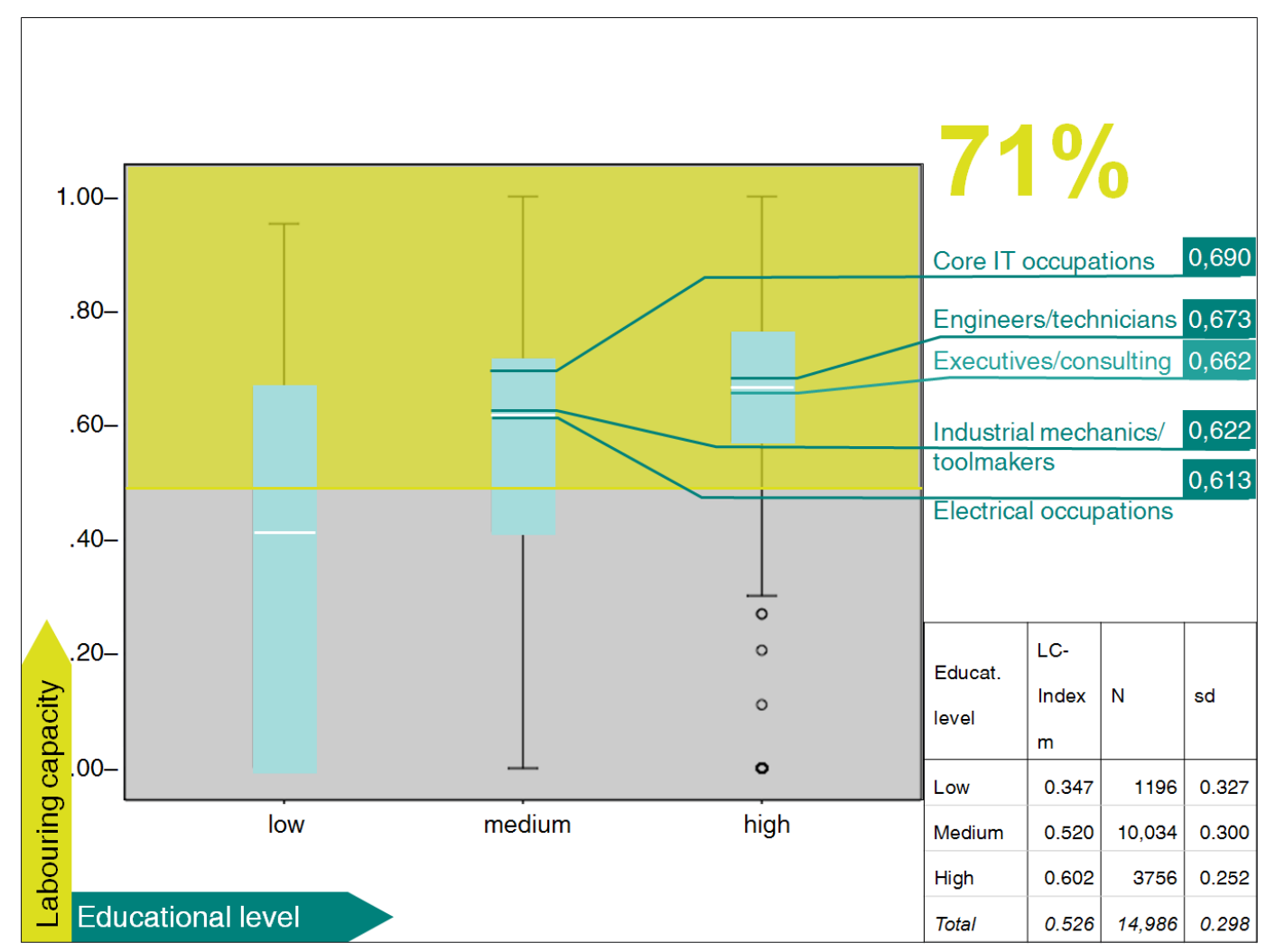

Figure 1: Labouring capacity (LC) index for educational level and selected occupations. $m$ mean; $N$ number of cases; sd standard deviation 
On 3 March 2015, Wirtschaftswoche ran the front-page headline "Industrie 4.0 scheitert am Menschen" ("Industry 4.0 fails because of humans"). There is no doubt that companies need to invest more in education and training to prepare for Industry 4.0 - even without the challenge of Industry 4.0, companies have had a considerable amount of catching up to do in recent years. However, it is also worth looking at available resources:

- 71 per cent of workers in Germany have living labouring capacity in dealing with complexity and unpredictability. They cope with multiple changes, and apply the necessary experiential knowledge to their work.

- The occupations that seem to be most needed for the implementation of Industry 4.0 scenarios display comparatively high values in the LC index. Here occupations with academic training and those with vocational training are intermingled in the rankings. Thus both training pathways lead to activities in which the ability to deal with complexity is already very much a requirement today.

If 71 per cent of the current German workforce has a high capacity to deal frequently with complexity and change, then the potential to cope with greater changes is already there. Anyone who is proficient in dealing with complexity on the basis of experience, and proves this in everyday work activity, will have no trouble coping with the additional formal qualifications and informal skills development necessary for Industry 4.0. However, the pathways to the relevant continuing education and training, both vocational and academic, must be made accessible for the individual, with more opportunities to transfer between the different training and education routes. 


\section{Dimensions of Industry 4.0 relevant to qualification}

There is no single, definitive version of Industry 4.0, and therefore no single answer to the question of the appropriate qualifications. Any discussion of possible qualification needs must involve differentiation and specificity. Earlier in this paper ( $\rightarrow$ section 1.1) we showed that not enough has been done to carry out these steps of differentiation and concretization. Besides fundamental industry-specific differences, it can be assumed that there will be diverging needs, depending on whether these are supplier or end-user companies, key manufacturers, system suppliers or downstream suppliers. Further differentiations will be necessary in future, in line with the phases of the implementation process, and dependent on the existing situation in each case. It must not be forgotten, moreover, that qualification requirements are most easily and accurately identified by participatory involvement of employees in the implementation of Industry 4.0. And qualification is ultimately also a question of will: do companies want a broad qualification base in the future, or do they aim to design technology in such a way that automation will supposedly make them independent of such qualifications in the future? The outcome of these processes of negotiation in society and the workplace remains to be seen; hence the following discussion concentrates on the technical aspects of Industry 4.0.

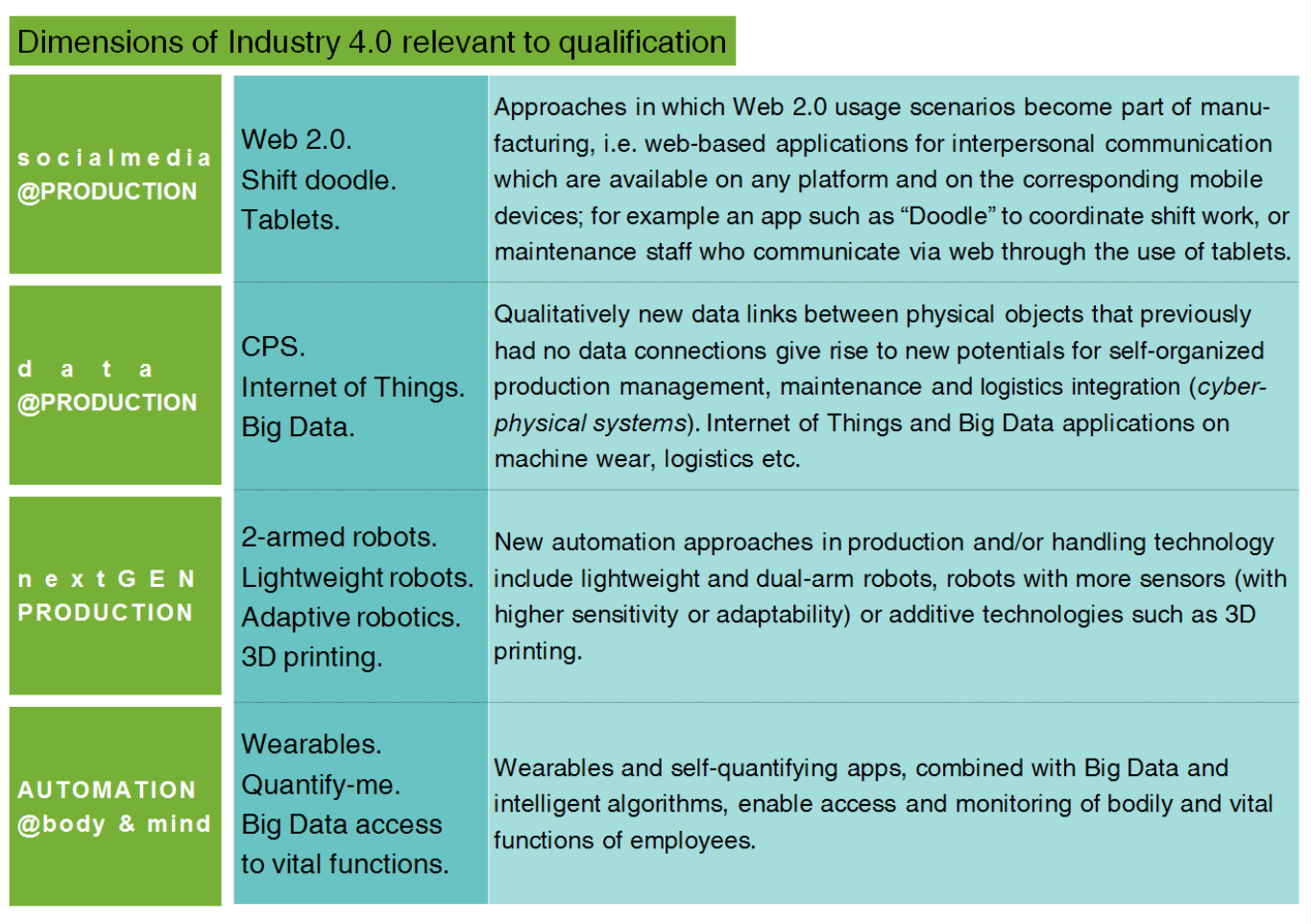

Figure 2: Overview of dimensions of Industry 4.0 relevant to qualification

This is not based on the idea that qualification requirements might be deduced from these factors - qualification is always far more than that, and this will not change, even in a possible new industrial revolution. Instead this approach is inspired by the fact that the necessary steps of differentiation and concretization have not been adequately carried out even on the technical 
level. However, not all the technical developments discussed under the label of Industry 4.0 will fully take effect everywhere. And not all technical developments will have the same consequences for qualification. Figure 2 shows an overview of the dimensions of Industry 4.0 which - judging from what we know today - will be relevant for qualification; these are then explained in the subsequent subsections and briefly illustrated with typical examples. This chapter thus lays the foundations for discussing the qualification requirements that may result from each of these four dimensions ( $\rightarrow$ section 6 ).

\section{1 social media@production: mobile web communication in production}

This is about approaches in which Web 2.0 usage scenarios become part of manufacturing, i.e. applications for interpersonal communication which are web-based, and therefore available on any platform and on the corresponding mobile devices. For example, an app such as "Doodle" might be used to coordinate shift work. These approaches are more in the nature of a catch-up, as social media use penetrates into areas of enterprise in which it has not previously featured. Strictly speaking, this is not about Industry 4.0 , but simply a change in communication media. Social media applications adapted for a particular usage can directly facilitate the exchange of experiential knowledge between employees, in a manner appropriate to the given situation. This is more likely to have effects on corporate culture than on employment and qualification. It may possibly help to exacerbate the general trend towards the blurring of boundaries between work and life, but as yet there has been no sign of a strictly industry-specific effect on work. Some typical scenarios in the near future, and specific applications that have already been partially implemented, are:

- "Shift Doodle" and Web 2.0: Employees use an app to confer in a group, or across different shifts, for example to decide who will come to work on Saturday if an extra shift is necessary. Web-based tools are also used for idea management and continual improvement processes. Everyone has access to these - wherever they are and whatever device they are on: whether in the workplace, from the workshop PC, from the production line, with the tablet, or from home with the smartphone. The service technicians also coordinate their work worldwide, e.g. arranging who will carry out the next customer service call in Brazil, or supporting each other when troubleshooting.

- Mobile devices for monitoring production (in-house or on the customer's premises): Thanks to new, largely self-controlling networks, production sequences no longer require as much intensive support as before. The staff no longer has to be on hand at all times. Fewer staff are needed, but these must be more highly qualified. The many sensors throughout the manufacturing sequence show the status of the system on mobile devices, and indicate when there is a need for intervention. 


\section{2 data@production: the integration of material production}

Qualitatively new data links between physical objects that previously had no data connection give rise to new potential for self-organized production management, maintenance and logistics integration (cyber-physical systems). They augment and expand previous steps towards computerization (such as ERP or PPC systems), and integrate these more closely with realworld value creation (within the company) and real-world logistics processes (via global value chains to the end customer). This potential for a new kind of permeation of the physical world by data paves the way for scenarios based on big data and intelligent algorithms. Major changes can come about on this level, leading to changed production sequences, new business models, and more fluid value chains. This development is most likely in areas that already have a high degree of computerization and automation, and will primarily lead to a huge increase in the complexity of the overall systems. It is not possible to estimate effects on employment and qualification in general terms, but these will occur - in very specific form - when the contents of jobs and the intersections between them change. Typical scenarios are, for example:

- Cyber-physical systems/Internet of Things: In a medium-sized enterprise, technically sophisticated gearwheels are manufactured in small batches. The status of different work steps (milling, grinding, hardening etc.) of different batches and the location of the different parts is recorded with the help of QR codes, which transmit data to an external service provider. The service provider uses this data to suggest optimized routes for the so-called "milk runner" (i.e. the person responsible for intralogistics, delivering parts to the relevant machines at the appropriate time) - the qualified logistician can then access these on his/ her tablet.

- Real-time parts/services tracking by customers: All sequences are digitalized in such a way that it is always possible to see how far the assembly of a machine has progressed, or what stage in the engineering design process a customer project has reached. Not only can all staff check the status of processes in the corresponding app - the customer can also be offered the option of tracking the processes related to his project in real time.

- Big data analytics in maintenance/remote servicing: The countless sensors in the machines and systems - whether in a company's own production line or when the machines/ systems are used on the customer's premises - constantly generate countless data. Technology that has already been used successfully in the past, for predictive maintenance or remote maintenance on the customer's premises, has now been developed further. Big data applications and intelligent algorithms allow data to be analysed constantly. This means that plant downtimes in-house and on customer premises can be considerably reduced, and spare parts can be produced and supplied in good time, before any signs of wear and tear. This saves costs internally and allows new business models.

- Personalization of products down to batch size 1: Increasing integration and more intelligent production sequences have made it possible to produce articles in an even more customer-specific way. Today, all products can be offered in batch size 1 - with a cost structure that was once only imaginable for large batch sizes and relatively standardized products. In some cases customers can already configure products themselves online, to meet their own very specific requirements. Here the data are fed directly into the engineering and then the production data for all subsequent steps.

- Production control by the product: Significant improvements have been made in the fine control of production, which is now decentralized. The product being manufactured virtually controls itself through the whole process. Every processing step, every quality test - everything is done largely automatically, as parts and machines exchange their data directly. 
The whole process requires human intervention much less often. Staff spend less and less time standing on the noisy factory floor; instead they monitor the process alongside other activities in a control room, and have time to spend in the communication-friendly "creative area", working on continuous improvement processes or looking at prototypes for new products. Even younger staff have now regained their interest in working on the shop floor, which has become a genuinely attractive workplace.

\section{3 nextGEN production: new production techniques}

New approaches in production and/or handling technology include lightweight and dual-arm robots, robots with more (and more sensitive or adaptive) sensors, additive processes such as 3D printing, and the use of drones. Inexpensive robots and drones are probably the innovations most likely to bring about decisive changes in areas that have so far, for economic reasons, had comparatively high proportions of human labour - e.g. transport and logistics, packing, delivery and shipping services, and manual or hybrid assembly. 3D printing or other additive processes will, within the foreseeable future, accelerate innovation cycles in the manufacturing sector (e.g. with rapid tooling), and will be important for internal departments such as toolmaking or testing. However, they will tend to bring about only incremental changes in the near future, and will have limited effects on work for specific occupational groups. Typical scenarios for the area of industrial production could be:

- Additive processes/3D printing: In just a few years, 3D printing has gone from a gimmick to a serious proposition. Today this technology can produce any materials needed with sufficient dimensional accuracy. This has considerably altered the processes in toolmaking, where rapid tooling is increasingly being used. The major sales and service centres, e.g. in Asia and the US, now also have 3D printers, allowing the fast production of individual, smaller spare parts, which can thus be delivered to the customer in a very short space of time. And joint development with customers - but also in-house, across different departments has become better and faster: for example, in order to develop more assembly-friendly or service-friendly products, individual system parts can now be quickly created as prototypes in the 3D printer - this facilitates communication and speeds up the development process.

- Dual-arm and lightweight robots: Large industrial robots were not financially viable in our company in the past. But as robots have become lighter and cheaper, it has become profitable to use them in more and more areas. For example, a dual-arm robot can be used for individual supply and insertion operations, and even for the packaging of spare parts. These activities - which used to be fairly undemanding - have now gone. The workers at these posts have received further training, and now look after larger areas of intralogistics. In assembly, these robots support older employees who have trouble with bending or other movements. 


\section{4 automation@ body \& mind - data-supported access to bodies and knowledge}

Wearables and self-quantifying apps, combined with big data and intelligent algorithms, expand access and monitoring into the bodies and vital functions of workers. This allows work processes to be designed more ergonomically, and ergonomics to be optimized for the individual. The guiding principle in production, the "avoidance of waste" can be followed right down to the smallest individual movement. This could also pave the way for work that takes into account the ageing process. At the same time, the recording of large, regularly gathered quantities of data presents unknown dangers - it offers unimpeded access to the subject and even the private sphere, which is very much related to the body. Typical scenarios in the near future could be:

- Wearables: Technologies which employees wear on their body are new. In assembly, for example, a smart glove helps workers to use the right techniques. Since products are becoming more and more diverse, assembly jobs have become more demanding: routine and constantly recurring sequences are virtually a thing of the past. The smart glove helps by indicating on a display if the wrong part is fitted or the wrong screw picked up. Smart glasses also help with the maintenance of machines on the customer's premises. They are not necessary for a real service call by the company's own experienced staff in a support case. But if the customer wants to replace a small wearing part himself, the instructions in the glasses help him to do it correctly. Expensive service callouts are only necessary for bigger and more complex support cases. On this basis, the company can offer a service package with monthly pricing.

- Recording of vital data: The data gathered by wearables during usage are analysed by means of intelligent algorithms. Employees can voluntarily connect their private fitness gadget (such as the smart watch) to the health module of the company software. They then receive recommendations for exercise and nutrition from both sources. The company's health management can use the non-personalized, aggregated data to see what the employees' state of health is like, and whether particular peak loads occur in certain departments. On the basis of a works agreement, it is technically impossible for superiors to see patterns in personal behaviour. 


\section{Qualification needs and target groups in terms of the Industry 4.0 dimensions}

If we wish to assess changing qualification needs in the light of these four technological dimensions of Industry 4.0, it is not enough to simply deduce these on the level of technical or operational knowledge. Usually it is comparatively quick and easy to make this assessment, but it is not always so easy to show to what target group the needs apply. The following section will assess, for each of the four technological dimensions of Industry 4.0:

1. What technical skills and qualifications are required, for what target group is this need relevant, and what institutional challenges are associated with it? This can best be answered by looking at the extent of the change on the level of the means, the object, and the organization of labour'.

2. How much does the complexity of the overall system increase? A rise in complexity can, on the one hand, lead to new technical challenges, but in businesses it is also always associated with an increased demand for living labouring capacity.

3. How much does good (robust, innovative and competitive) implementation of the technical solution require participatory design by employees? The more systemic the innovation is, and the more extensive the impact of the change, the more necessary it is to involve the employees and their technical and experiential knowledge right from the start.

\begin{tabular}{|c|c|c|c|c|c|}
\hline & \multicolumn{5}{|c|}{ Industry 4.0 and influence factors - demands for qualification } \\
\hline & \multirow{2}{*}{$\begin{array}{l}\text { Participation } \\
\text { Design process }\end{array}$} & \multirow{2}{*}{$\begin{array}{l}\uparrow \text { Increase } \\
\uparrow \text { Complexity }\end{array}$} & \multicolumn{3}{|c|}{ Extent of change } \\
\hline & & & Means of work & Object of work & Work organisation \\
\hline $\begin{array}{l}\text { so cial m edia } \\
\text { @PRODUCTION }\end{array}$ & $\begin{array}{l}\text { Only effective if } \\
\text { shaped by emp- } \\
\text { loyees according } \\
\text { to their needs. }\end{array}$ & \multicolumn{4}{|c|}{$\begin{array}{l}\text { Comparatively unproblematic, often familiar from everyday use. Learning by } \\
\text { doing is possible. Knowledge of control, transparency, performance increase } \\
\text { in importance. }\end{array}$} \\
\hline $\begin{array}{l}d \text { a } t \text { a } \\
\text { @PRODUCTION }\end{array}$ & $\begin{array}{l}\text { Only shapeable } \\
\text { with input of tech- } \\
\text { nical and practical } \\
\text { knowledge of } \\
\text { employees. }\end{array}$ & $\begin{array}{l}\text { Labouring } \\
\text { capacity increases } \\
\text { in importance, but } \\
\text { more difficult to } \\
\text { realise. }\end{array}$ & \multicolumn{3}{|c|}{$\begin{array}{l}\text { Disruptive change. Increasing demand for formal } \\
\text { qualification in data handling and ability to relate off- and } \\
\text { online. Upgrading of qualification in industrial and logistic } \\
\text { core skills, risk of downgrading at margins. Contents of } \\
\text { demanded qualification can hardly be determined ex ante. }\end{array}$} \\
\hline $\begin{array}{l}n \in x t G E N \\
\text { PRODUCTION }\end{array}$ & $\begin{array}{l}\text { Only shapeable } \\
\text { with input of } \\
\text { technical and } \\
\text { practical } \\
\text { knowledge of } \\
\text { employees. }\end{array}$ & $\begin{array}{l}\text { New labouring } \\
\text { capacity emerges. }\end{array}$ & \multicolumn{2}{|c|}{$\begin{array}{l}\text { Machine operation skills can be } \\
\text { acquired incrementally if starting } \\
\text { from skilled worker qualification. }\end{array}$} & $\begin{array}{l}\text { Partially new } \\
\text { procedures, new } \\
\text { proximity to custo- } \\
\text { mers, increased } \\
\text { complexity. }\end{array}$ \\
\hline $\begin{array}{l}\text { AUTOMATION } \\
\text { @body \& mind }\end{array}$ & $\begin{array}{l}\text { Develop with } \\
\text { employees to } \\
\text { avoid misuse } \\
\text { and strengthen } \\
\text { benefits on their } \\
\text { behalf }\end{array}$ & $\begin{array}{l}\text { Danger of under- } \\
\text { estimating practical } \\
\text { knowledge. } \\
\text { Acquisition of new } \\
\text { practical knowledge } \\
\text { more difficult. }\end{array}$ & \multicolumn{3}{|c|}{$\begin{array}{l}\text { Depending on principal design decisions: little qualification } \\
\text { demands in case of mere support of humans. Otherwise } \\
\text { risk of systematic downgrading of qualifications. }\end{array}$} \\
\hline
\end{tabular}

Figure 3: Industry 4.0 and influencing factors - requirements of qualification 


\section{1 social media@production: comparatively unproblematic}

New operating options and mobile devices are becoming part of workplace reality, and are now advancing into production. New web tools, apps and mobile devices such as smartphones or tablets require adaptive learning here and there, but this is largely unproblematic, for several reasons. Firstly, these applications - and this is part of their success - are easy and comparatively intuitive to operate. Secondly, many employees are already familiar with using them in their private lives - developments often take place here before they become part of everyday working life. Thirdly, in the technical environment of production, a large proportion of employees are already confronted with much more technically demanding systems, which are usually not so intuitive to use. In comparison, dealing with the new gadgets and apps can be learnt without any great trouble. A challenge arises, however, from the usual assumption that younger employees do not require any support here, while a special effort must be made to introduce older employees to these new applications. Both these assumptions may be true in individual cases, but often the reality is different. Young people may have grown up with social media and tablets, but they generally only know these as part of everyday life in their teens - effective use of these tools in a production environment is often a new challenge for them. Usually, however, neither the younger employees nor their managers realize this. Younger workers are therefore often not included; there is an untested assumption that they already have all the necessary knowledge. This leads, unnoticed, to quite unnecessary qualification deficits. Older workers, on the other hand, do increasingly use Web 2.0 applications and smart phones: they book trips and rate their hotels, they connect with old school friends on Facebook, and communicate with their adult children via WhatsApp or Skype. If, when social media or mobile devices are introduced at work, these workers are faced with discriminatory assumptions about age-related deficits, then problems with acceptance are to be expected. Here the key to qualification lies in an open work climate, characterized by humour, reciprocity, and scope for experimentation. A climate that also, however, allows different needs, and accepts that these cannot simply be deduced from the age of the employees. The technical requirements for operation are comparatively low and could be learnt by doing. It is important to ensure that no age discrimination occurs. The key target group for qualification is the managers rather than the employees.

Similar things can be said about the change in the work context, and the increase in complexi$t y$. Both are comparatively unproblematic in this dimension; here it is not so much operational knowledge that is required as knowledge about the potential for monitoring (in some cases indirect or time-delayed), and about the new visibility and performative quality of one's own work behaviour. Here technical knowledge plays a larger role than experiential knowledge. But as this involves the introduction of an additional level of communication, rather than any substantive changes on the level of work equipment, work object or work organization, the associated requirements for both technical knowledge or skill and experiential knowledge are much less demanding than for the other Industry 4.0 dimensions.

In contrast, the living labouring capacity of employees is of particular importance for the design of systems and during the process of implementation. If the use of social media is actually to have positive effects on the quality of communication between employees or the generation of ideas, it is not enough to implement some platform or other on a purely technical level. If the platform offered does not match the specific work requirements and processes, the new Web 2.0 services will either languish unused, or companies will have to keep devising new incentives to increase their use - measures that will always have only short-term effects. If, however, the design follows the principle of "work based usability" (Pfeiffer/Schmauch, 2010), and focus- 
es on the real needs of specific work, and if, in the selection and design of the systems, the special quality of informal knowledge is acknowledged and systematically taken into account, then the introduction process will be more reliant on the experiential knowledge of the employees. In the subsequent use phase, however, this extra effort in the design phase will lead to much higher acceptance and joy of use, without the need for constant incentivization. In this dimension, it is mainly the executive and management levels that will require additional qualification and training.

\section{2 data@production: the integration of material production}

It is this dimension that contains the real changes in what is usually referred to as the core of Industry 4.0. This is also the place with the greatest potential for disruptive changes - which, however, are not necessarily always visible at first glance. On the contrary: the processing methods and the technologies used can often remain largely unchanged. What is new is the increased number of sensors and embedded systems, coupled with big data analysis of the incoming process data. This can then be the basis for intelligent analyses of plant conditions or the optimization of fine control of production. To understand the new requirements this creates for qualification, it is worth beginning with an analytical breakdown into the offline and online sides of the process:

In terms of production technology, then, employees on the factory floor have to learn relatively little new material here - but this does not mean that the "offline" side of CPSs is becoming less important. On the contrary, to remain competitive it is vital to retain and continue generating the necessary technical and experiential knowledge. This is also a strategic issue: at present we are still more or less in the initial phase of a widespread digitalization of production, and it seems as though everything that has to do with data is relevant and crucial for competition. If we imagine the world just a few years on, however, things might change: offline could become the new online, so to speak. Once the IT infrastructure needed for Industry 4.0 has become universally established, once standards for CPS networks have been set, once production-related cloud service providers and big data analysis tools have begun to offer robust, economically viable services - then the data side, the online side, will become a basic technology, which can be purchased with the necessary investment capacity, and whose technological core can be copied. Once this has happened, those things that are not copiable will gain even more importance, especially in global competition. Particularly important will be those processes requiring knowledge and skill that cannot simply be transferred in databases - in other words, knowledge about specific details of production technology, the ability to start up and run complex systems, the skill to harmonize various production and process steps in an economically effective and qualitatively robust manner. In short, abilities that are characteristic of the skilled worker level.

In addition to the offline skills that are worth retaining, the online side also brings expanded requirements. Undoubtedly, the demands for formal qualifications relating to data handling will increase. Not everyone has to be able to program, but obviously skilled workers are likely to face higher demands in this area. However, a mechatronics engineer who is now proficient in PLC programming will have no trouble coming to terms with another programming logic or other programming languages. On this level, the established forms of education and training should be able to keep up with these incremental steps. There are, however, two other issues on the online side which are new: data protection and privacy issues require considerably more knowledge, 
and a general sensitivity to the issue - even in workplaces where this has not previously been necessary. Many tasks, though, will no longer be able to be delegated to the data protection officer or the IT department. In future, more guidelines for the organization of such issues can and must be provided on the level of workplace co-determination; on a daily basis, however, many more employees than today will have to make small decisions and carry out individual technical actions which may be relevant for privacy and/or data protection. The content necessary for this has to be integrated into formal training programmes. The increase in data and in support tools for visualizing and analysing data brings skills requirements that have not really featured in production so far: it is becoming increasingly necessary to understand the power and the limitations of algorithms. This also includes understanding the difference between causality and correlation, and the difference between the computerized representation and the real processes behind it.

Critical new requirements will arise at the intersection between offline and online. This begins with the design of the systems. Employees must learn to express their needs clearly to IT/software developers, and to argue their case. On the other hand, IT/software developers must learn to understand real needs better. This has not been very successful so far. Hence both sides need to know more about the best way to facilitate the design of complex technical systems. This includes methodological knowledge on processes of participatory technology design. The second point is that the ability to bring together the offline and online sides of CPSs, i.e., to effectively relate the special features of the material production process to the information present in data, has to do with the level of ongoing operation. Production staff, but also system designers and IT staff, all need a greater ability to operate confidently in both worlds, and above all, to continually relate these to each other. The abstract quality of the data world must be constantly re-concretized, and the concrete - i.e. the material processes, parts, and technologies - must be reconnected to the abstract representation. Ultimately, the interlinking of the two sides is also a question of innovation: real innovations and new business models will only be achieved by those companies whose employees are in a position to recognize the online potential in the concrete aspects of offline processes, and, conversely, to generate new approaches for actual value creation from options in the data world.

More IT knowledge, and more quickly changing IT knowledge, will be required at the skilled worker level. The real challenge, however, will lie in the ability to bring together the offline and online sides of CPSs, in their design and their day-to-day operation.

\section{3 nextGEN production: new content, different players, unrecognized opportunities}

In the case of new technological processes such as 3D printing, the first thing to be clarified is which occupational profiles or which courses of study need to include teaching on the corresponding subject knowledge. Secondly, we need to estimate when these technologies will have become sufficiently widespread that it makes sense to include them as fixed components of selected technical occupational profiles and courses of study. Such estimations are not new, and have a well-established institutional tradition, particularly in the dual system. The actors involved are familiar with the procedure, as it has been carried out repeatedly in the fields with other technological innovations (laser cutting, new welding techniques, high-speed milling, EDM etc.). Both in higher education and in the dual system, there are functioning and largely adequate mechanisms for assessing when, and in what form, this knowledge should be integrated 
into which training curricula. This step must be taken again, but ultimately it is a familiar step; the only difference is that - in view of the dynamic pace of the new development - it will have to be taken more quickly than in previous years. At the same time - and here the dual system is more transparent and more reliable in its processes than academia - the most recent restructuring (e.g. of the metalworking occupations) created considerably more scope for development within the individual training occupations (Ausbildungsberufe). This already allows companies to respond quickly to new technical developments and the related qualification needs, even during current training contracts. Thus companies already have many options in the area of dual training, but a creative, forward-looking attitude is needed if these are to be sufficiently utilized. The established mechanisms for adapting occupational profiles and curricula, and the existing flexibility in the organization of in-company training, offer a largely adequate institutional setting to meet the qualification needs that arise from new developments in production technology. The actual qualification challenge, especially with regard to teaching staff in universities, vocational schools, and companies, is to make proactive use of the existing options.

In the case of innovations in production technology, the supply industry and the manufacturing side traditionally play a key role in training and qualification, a role that end-user companies have so far been able to rely on. If a medium-sized company buys an expensive industrial robot, the purchase price usually includes introductory training, and larger vendors operate whole training centres with sophisticated training methods. Partly driven by marketing or customer retainment strategies, large vendors often offer their machines or robots and the related seminar modules at a lower price for training in companies, but also in universities and vocational schools. The role of the vendors in machine and plant engineering as "hidden" educational actors has its roots in tradition, and is thus taken for granted by most actors in the qualification field and in the companies. As new players enter the market, however, this may change. For one thing, start-ups that do not come from a typical mechanical engineering culture may not see themselves, in a systematic sense, as providers of qualification solutions. More importantly, however, they would have to set up and maintain seminar rooms and training programmes with the corresponding personnel - a requirement which many will be unable to fulfil, at least in the start-up phase. For another thing, the investments for smaller 3D printers or lightweight robots are substantially lower than for their technological predecessors - this will tend to reduce vendors' willingness to offer training as a regular add-on to the hardware. Falling investment costs and new start-ups are changing the unofficial training role previously played by supplier companies - training and qualification will no longer be a normal add-on to the purchase of capital goods, especially in the case of the new technologies. This leads to an underestimated challenge, especially for SMEs.

These falling investment costs also mean opportunities, however: it will become easier for vocational schools, university laboratories and teaching workshops, even those in medium-sized enterprises, to acquire this technology purely for training purposes. Agile and strategically oriented universities and inter-company training providers may move into these qualification gaps - though this may only be necessary during a transitional period - and devise specific continuing education programmes. Another area of potential that has so far not even begun to be recognized, let alone tapped, lies in the field of the new robotics and the additive processes. Unlike the other three dimensions of Industry 4.0 that are relevant to qualification, this is technology that can be physically perceived and experienced. And it is technology that - outside industrial applications - has already found a place in the hearts of many young people. The movement of the "makers", DIY and "fab labs" show, especially in 3D printing, that even the Millennials and Generation $Z$ can get excited about technology. Vocational schools and teaching workshops offer everything that fab labs need in the way of technical equipment - this could be an opportunity for new and innovative collaborations between business, the public sec- 
tor and civil society. It would be a more effective way to catch young people early on and attract them to technical training pathways - and also to introduce older teaching staff to technologies that are new to them too, by working with the maker movement and learning by doing.

Innovations in product technology offer special opportunities: the cheaper technology can more easily be purchased for educational purposes, and it can be directly experienced. This opens up new options for cooperation between traditional educational actors and civic engagement, giving both younger and older people a lasting interest in the new technology, and at the same time qualifying them to deal with it.

\section{4 automation@ body 8 mind - data-supported access to bodies and knowledge}

These approaches are least specific to Industry 4.0; they will also play a role in areas beyond manufacturing. The main areas of knowledge required will again be those discussed above ( $\rightarrow$ section 6.2 ): obviously privacy and data protection are central here.

Apart from this, the crucial challenge here is not to establish what has to be learnt in order to deal with a technology once it has been introduced. Instead the content - and ultimately the timeframe - is the other way around. The question that must be asked - again and again, in the context of the workplace - is the following: should skilled work retain its importance, and only those wearables be used which serve to support the special abilities of human workers? Or is the dominant idea that, for example, the "smart" glove gives the more or less unskilled worker a technical demonstration, so to speak, of what to do next? These are normative, preliminary decisions, which need to be negotiated in society and in the workplace, and which lead to fundamentally different design premises. Thus the discourse about the premises and aims of technology design is the predominant competency requirement at this level. This goes well beyond questions of traditional qualification and training, and is ultimately a learning process for society.

\subsection{Transversal competences, new forms of learning, new target groups}

The previous representation of qualification requirements was deliberately based on four facets of Industry 4.0 which can be described mainly in terms of technology - this analytical perspective was intended to allow a clearer representation, and not to imply that qualification requirements arising from Industry 4.0 can be deduced from precisely these technologies. When assessing the possible impact of change in the workplace, it is always helpful to ask: do Industry 4.0 approaches change anything on the level of work equipment, work object, or work organization? If this question can be answered with 'yes' on one or more counts, this is a fairly certain indicator of imminent qualification needs. The next step is then to define the content of these needs, and to clarify in what formats and forms this qualification can most effectively be provided. Here the new German training occupations (Ausbildungsberufe) - such as the production technologist - offer enough scope to integrate relevant work-related specifics, even in the initial dual training. 
If, in the context of Industry 4.0, there are changes in work equipment, work object, and work organization, this not only affects formal qualification requirements. The associated change requires workers to utilize their experience and living labouring capacity ( $\rightarrow$ section 4.2 ). The earlier employees are involved in shaping this change, the more easily they can acquire new experiences in this process, and thus continue to develop their living labouring capacity - this dynamic resource grows simply "by doing". The key, then, is no more and no less than participation from an early stage. The following graphic shows these three influencing factors in the three blue-green columns on the right. The representation is to be understood as follows: the more the blue-green circles are filled in, the higher the estimated requirements.

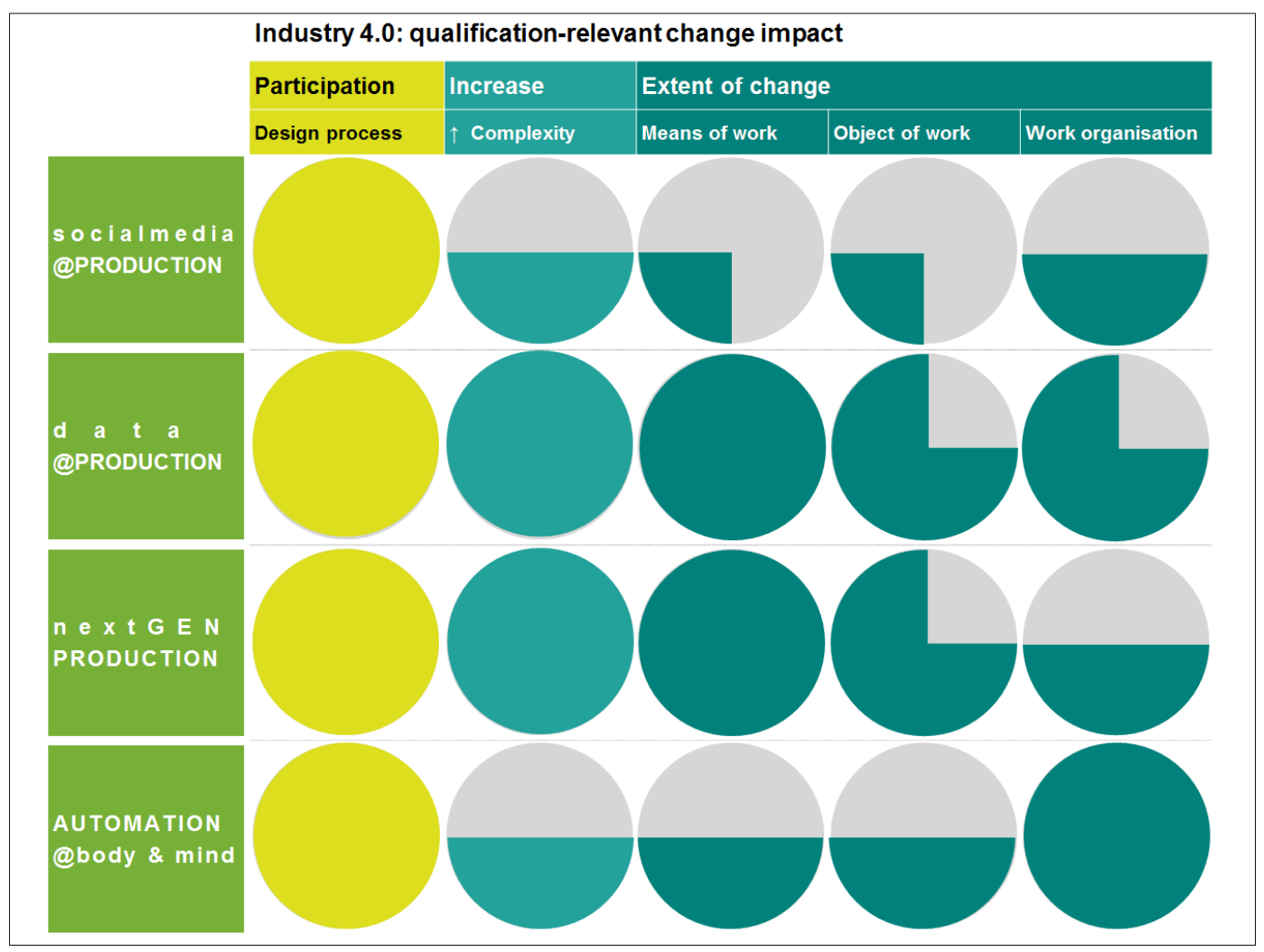

Figure 4: Impact of change relevant to qualification

The same graphic shows, in the two columns on the left, two further influencing factors resulting from Industry 4.0: design/planning in participatory processes (yellow-green) and increase in complexity (blue-green). With two exceptions, all the circles are completely filled in here; the assessment is that experience or living labouring capacity plays a particularly important role here.

At this point, three arguments will conclude this overview of the demands that may be placed on qualification, and on the experiential knowledge of employees:

1. On the way to Industry 4.0 - and this applies more now than in the past - it is not primarily the technical content that is critical, as this will change faster than has hitherto been the case. Much more relevant are the methods of teaching. Right from the initial vocational education and training, it will be necessary to develop individuals who can think on their feet and act independently. This also means that trainers and vocational schools face a completely new set of tasks. 
2. As set out in $\rightarrow$ section 1.1 , social competencies are repeatedly identified as something that will be more in demand because of Industry 4.0. It is not enough, however, to evoke the need for better teamwork skills. In future it will not just be people with the soft skills for teamwork who are needed. Industry 4.0 requires people who are capable of inter- and transdisciplinary collaboration (i.e. across different subject areas, and with other departments, companies, customers and/or civil society). Again, this is an ability that must be fostered from the initial training onwards. At the same time, this collaboration with others, and above all with other stores of knowledge and experience, is the vehicle for acquiring a capacity for systemic thinking.

3. Up to this point, this report has mainly considered what additional knowledge and skills employees need to acquire in Industry 4.0 - or on the way to it. More than once, however, it has also stressed that the methods of learning, and the early involvement of employees in the development of Industry 4.0 by way of participatory processes, are crucial in two respects: firstly, for the design of better technology and better work, and secondly, because this means that a large part of the necessary learning and experiential processes are accomplished by doing. However, allowing new forms of learning and participation is "a matter for the bosses", i.e. the real target group for learning processes of this kind is not, in the first instance, the employees, but their managers. It may be that there are more problems to be remedied here than the current discourse on Industry 4.0 suggests. 


\section{Summary and options for action}

There is no doubt that the demand for systemic thinking and interdisciplinary collaboration will increase. Not everyone will have to be capable of programming and modelling, but more employees will need an understanding of IT and data structures. We will therefore need more formal qualification and training in data handling - but without giving up on know-how about production technology. On the contrary, the main concern will be to relate offline and online elements to one another. A further requirement will be more knowledge about the power and the limitations of algorithms. This includes, for example, understanding the difference between causality and correlation. All employees will have to do a good deal of extra learning when it comes to data protection and privacy.

As Industry 4.0 is mainly a design issue, it is much more important now than in the past that designers and users learn to talk to each other in participatory processes: employees must be able to express their requirements to IT developers, and also to argue their case. And conversely, IT developers and system designers need to learn, even better than before, to incorporate the needs of workers and customers into the development process at an earlier stage. What is frequently forgotten is that it is not only employees who have to learn a few new things here. This applies even more to management. Whether our managers are ready for Industry 4.0 is, in my view, an unanswered question. The preceding remarks, especially in $\rightarrow \mathrm{ch}$. 6 , are conceived as specific recommendations for action. Here the qualification requirements arising from Industry 4.0 will be briefly mentioned, in terms of four identified dimensions:

\subsection{Qualification requirements arising from Industry 4.0}

Industry 4.0 is a wide-ranging set of change options. Wherever something changes on the level of work equipment, work object, or work organization, it can be assumed that qualification needs will arise or change. The specific content of these needs must then be identified, and they must be translated into suitable qualification formats. Here newer training occupations (Ausbildungsberufe) - such as that of production technologist in Germany - offer enough scope even in the initial training. In addition, the following points can be summarized on the four levels:

- socialmedia@production: As social media and mobile devices become part of production, the technical skill required simply to use them is relatively low. This can be learnt by doing. Care must be taken that there is no discrimination on the basis of age. The key target group for qualification is management rather than staff.

- data@production: As industry becomes more integrated as a result of CPSs and the Internet of Things, more IT know-how and rapidly changing IT knowledge will be needed, even at the skilled worker level. The real challenge, however, lies in the ability to relate the offline and online sides of CPSs in their design and in day-to-day operation.

- nextGENproduction: The established mechanisms for adapting occupational profiles and curricula, and the existing flexibility in the organization of training in the workplace, generally offer enough scope to respond to qualification needs arising from new applications in production technology, such as new robotics and additive techniques. The sectors facing new challenges will tend to be those that have previously had little experience with automation, but will now be severely affected (e.g. logistics, which will be affected by lightweight robots). 
However, the cheaper technology also has the potential to be integrated more quickly into the education sector; for example, vocational schools could establish themselves as fab lab providers.

- automation@ body \& mind: When it comes to the use of wearables, or access to the activities of employees by means of big data, the key qualification challenge lies with the technology developers, not with the users. The main focus of learning will be on how the premises and aims of technology design can be discussed and decided in participatory processes.

\subsection{Transversal competence requirements as part of modern professionalism need the duality of learning venues}

Besides the qualification requirements that arise in direct connection with the technical phenomena of change, certain transversal competency requirements play an ever more important role in an increasingly digitalized world of work. Preparation for these must be offered in all training formats, qualification pathways and levels of education. They include not (only) the ability to work in a team, but also the capacity for inter- and transdisciplinary collaboration; not (only) the ability to abstract, but also the capacity to link the material and the abstract, the concrete and the digital; not (only) IT knowledge, but knowledge about the limitations of algorithms, and the risks to data security; not (only) the ability to deal with the unforeseen, but also the capacity to think systemically and act confidently in conditions of uncertainty; not (only) improvisation in fixed frameworks, but creative development of new things. These abilities are neither a "soft" add-on to "hard" technical knowledge and skills, nor do they replace the latter in the sense of generic competencies. They are formed in and through professional activity, they are an indispensable part of modern professionalism, and they can only emerge in the duality of different learning venues and workplaces conducive to learning.

To complete this discussion, we will mention a few central issues following on from the above remarks, issues that need to be borne in mind on the way to Industry 4.0, when it comes to the topic of qualification. These are grouped by content, and are directed sometimes at one main target group, sometimes at more than one.

\subsection{Recognizing and utilizing living labouring capacity as a resource for the development of Industry 4.0, and creating the conditions for participation}

The experiential knowledge primarily acquired in the context of work and everyday life is, alongside formal educational qualifications, an indispensable but often underestimated resource in dealing with complex, heavily digitalized working worlds - and on the way there $(\rightarrow c h$. 4$)$. If this special resource is to be utilized for the development of Industry 4.0, a much higher level of participation is necessary. Some examples of what this could mean for the different target groups are as follows:

- Target group: policymakers. Promoting measures that encourage more theoretical and methodological knowledge about participation: in companies, among social partners, and in 
higher education institutions. Creating incentives to set up research groups and competence centres focusing on participation as a basis for action and a learning objective. A yet-to-beestablished research monitoring system (see below) would require new approaches, to ensure that the informal - and non-automated - side of action is more visible and is valued more highly.

- Target group: companies. Companies must learn to acknowledge employees' experiential knowledge more, and to utilize it at an earlier stage when designing changes in work organization and/or the technologies used. Organizational structures and the classification systems used in organization development and human resource development need to be based on greater participation. The participatory capacity of both staff and management should likewise be fostered and systematically developed.

- Target group: higher education. Courses of study in engineering and information science need to be expanded to include knowledge about participation processes and the related methodological skills. Theoretical and methodological knowledge about relevant approaches (workplace innovation, social innovation, action research, design thinking, agile methods etc.) needs to become part of the established canon of technology and engineering courses. Programmes for training future managers in the higher education sector, and continuing development for existing managers, should also be expanded to include a strong focus on participatory management styles and democratic forms of enterprise.

- Target group: social partners. Besides institutionalized negotiation processes, the social partners should make more use of additional forms of participatory inclusion, allowing employees more input into the development of regulatory instruments (e.g. works agreements). In some cases their own forms of organization will need to become more open, and trade association representatives and union officials will need more skill in recognizing the different and sometimes contradictory needs of employees, and finding creative solutions.

\subsection{Making skilled labour and the dual system of initial and continuing training more robust and more attractive}

The vocational education and training system has obviously lost its appeal for many young people, while at the same time losing its power to integrate. Yet it remains an indispensable building block for the future-proof development of Industry 4.0, and its attractiveness needs to be restored (cf. $\rightarrow$ ch. 3 ). This cannot be achieved with marketing alone; what is needed is a dynamic renewal of proven strengths. For the different target groups, this could mean, for example:

- Target group: policymakers. Occupational profiles must be modernized more vigorously and opened up in terms of methods. Policymakers can create the framework and conditions for this. For example, the social partners should continue to be included in all change processes. Occupational profiles should not be prescriptive, and imposed by bureaucratic decree, but should create secure and reliable frameworks for employees and companies as actors on the labour market. The mechanisms for changing the content of occupational profiles should be checked and purged of bureaucratic superstructures, to make them more responsive, now and in the long term. New technical processes should be made widely available early on by means of extra inter-company training programmes. Full-time and parttime training staff in the companies, as well as other institutional actors in vocational education and training, should be offered continuing development programmes to modernize 
their teaching content and methods. This might be achieved by working with the social partners to support continuing education centres at universities. Vocational schools must be modernized, and their teaching staff must be offered continuing education and training - not only in the area of IT and data security, and in the new technologies, but, more importantly, in new and participation-based learning methods. This also requires modernization of the technical equipment and premises of the vocational schools. Vocational schools should be encouraged to offer fab labs and to establish themselves as centres of the maker movement.

- Target group: companies. Companies should make more active use of the existing methodological openings and moves towards process and action orientation in the occupational profiles, and adapt these to fit the workplace. In human resource development, more systematic consideration should be given to the role of the trainer, with younger trainers being developed from an early stage, and encouraged to embrace modern methodological/didactic approaches from the start. As soon as workers are hired after their initial training, and in all subsequent career steps, the importance of vocational education and training should be emphasized, and comparable prospects for development should be pointed out. More efforts must be undertaken to make the manufacturing jobs of the future attractive, and to ensure that they are able to compete with areas of non-material knowledge work, e.g. with regard to autonomy in working hours, shifts and work location. Joint inter-company forms of training between companies and start-ups not only make it easier for companies to create more up-to-date and technologically diverse training programmes; they also make the training more appealing to young people.

- Target group: higher education. Universities should devise more programmes to support companies in integrating didactically new methods into initial training, so as to develop systemic thinking and the capacity for inter- and transdisciplinary collaboration right from the beginning. Universities should create real transfer opportunities between the vocational and academic paths to initial and continuing training, with the aim of raising the status of initial vocational training in comparison to the bachelor's degree. Universities must become more open towards dialogue with social actors from the labour market and (from) companies i.e. with social partners - without losing their special academic nature and their broad educational mandate, or simply becoming an instrument of market interests. This danger is lessened if accrediting agencies or committees such as university councils, where they are already open to non-academic actors, consult the interests of the social partners on an equal basis.

- Target group: social partners. Start-ups are often unfamiliar with the possibilities of the dual training system, so it is important to win their support for the idea of this system. Policymakers can create the framework and conditions for this, but it is up to the social partners to provide a point of contact and assistance when the system is first implemented. It is in their interest to gain newly emerging companies and their staff as members. This motivation should be utilized more to market the dual model to the new entrepreneurs, who often come from a purely academic background. 


\subsection{Creating the conditions that make change possible}

Be it Industry 4.0., the energy transition or electromobility: in the world of work, as in society, we are increasingly confronted with innovations of systemic proportions, which cannot simply be broken down into small sets of required skills. Looking at the overall picture, the question that arises is not just how individuals - whatever their role - are or become able to cope with the change. The other question is to what extent the established institutional systems are in a position to give the change a formative framework, one which is forward-looking without allowing previous strengths and social values to erode unseen. We will therefore conclude with a few recommendations for action, with a perspective that reaches beyond the immediate issues of qualification:

- Target group: policymakers. Establishment of a research monitoring system, which carefully records the qualitative changes in the companies and systematically links this with wideranging quantitative surveys. This will allow prompt identification of steps that need to be taken in terms of policy, giving different actors in business and society transparency and clearer orientation. Strengthening the social partnership, expanding co-determination around issues of informational self-determination, and supporting this with legislation so that it is effective even where there is no strong workplace representation.

- Target group: companies and social partners. Previous overlaps and antagonisms around the issue of regulation need to be overcome. It is no longer a matter of more regulation or less, but of creating generally agreed guidelines, which protect both the "middle" of employees and small to medium-sized enterprises from a drive towards deregulation, which is supported by digital technology and accelerated by globalization.

- Target group: higher education. At all levels of qualification, especially at executive level, skills in dealing with the power and the limitations of data must be made a learning objective. This is a task not only for the technical disciplines, but also for the fields of economics and teacher training. 


\section{References}

acatech (2015): Digitale Vernetzung und Zukunft der Wertschöpfung in der deutschen Wirtschaft. Dossier für den 2. Innovationsdialog in der 18. Legislaturperiode. Berlin: Deutsche Akademie der Technikwissenschaften.

Ahrens, Daniela; Spöttl, Georg (2014): “Attraktivitätsverlust der Berufsbildung?”. In: WSI-Mitteilungen (8), pp. 645-646.

Ahrens, Daniela; Spöttl, Georg (2015): "Industrie 4.0 und Herausforderungen für die Qualifizierung von Fachkräften”. In: Hirsch-Kreinsen, Hartmut; Ittermann, Peter; Niehaus, Jonathan (eds.) Digitalisierung industrieller Arbeit. Baden-Baden: Nomos, pp. 185-203.

Alda, Holger (2013): Tätigkeitsschwerpunkte und ihre Auswirkungen auf Erwerbstätige. Bonn: BiBB (Schriftenreihe des Bundesinstituts für Berufsbildung).

Antonczyk, Dirk; Fitzenberger, Bernd; Leuschner, Ute (2008): Can a Task-Based Approach Explain the Recent Changes in the German Wage Structure? (Discussion Paper Nr. 08-132) Mannheim: ZEW Zentrum für Europäische Wirtschaftsforschung.

Antoni, Conny H.; Haunschild, Axel; Meyer, Rita; et al. (2013): "Niemand weiß immer alles": Über den Zusammenhang von Kompetenz- und Organisationsentwicklung in der Wissensarbeit. Berlin: Edition Sigma.

Baethge, Martin; Solga, Heike; Wieck, Markus (2007): Berufsbildung im Umbruch. Signale eines überfälligen Aufbruchs. Berlin: Friedrich-Ebert-Stiftung.

Bauer, Hans G.; Böhle, Fritz; Munz, Claudia; et al. (2006): Hightech-Gespür: Erfahrungsgeleitetes Arbeiten und Lernen in hoch technisierten Arbeitsbereichen. Ergebnisse eines Modellversuchs beruflicher Bildung in der chemischen Industrie. Bielefeld: Bertelsmann.

Bauernhansl, Thomas; Hompel, Michael ten; Vogel-Heuse, Birgit (eds.) (2014): Industrie 4.0 in Produktion. Automatisierung und Logistik. Anwendung - Technologien - Migration. Wiesbaden: Springer Vieweg.

Bauer, Wilhelm; Schlund, Sebastian; Marrenbach, Dirk; et al. (2014): Industry 4.0 - Volkswirtschaftliches Potenzial für Deutschland. Berlin: Bitkom.

Blanchet, Max; Rinn, Thomas; Thaden, Georg von; et al. (2014): Industry 4.0. The new industrial revolution. How Europe will succeed. Munich: Roland Berger Strategy Consultants.

BMBF (2014): Berufsbildungsbericht 2014. Bonn: BMBF.

Böhle, Fritz; Bolte, Annegret; Drexel, Ingrid; et al. (2009): Umbrüche im gesellschaftlichen Umgang mit Erfahrungswissen. Theoretische Konzepte, empirische Befunde, Perspektiven der Forschung. Munich: ISF München.

Böhle, Fritz; Milkau, Brigitte (1988): Vom Handrad zum Bildschirm: Eine Untersuchung zur sinnlichen Erfahrung im Arbeitsprozeß. Frankfurt/M., New York: Campus.

Böhle, Fritz; Pfeiffer, Sabine; Sevsay-Tegethoff, Nese (eds.) (2004): Die Bewältigung des Unplanbaren. Wiesbaden: VS Verlag für Sozialwissenschaften.

Bosch, Gerhard (2014): "Facharbeit, Berufe und berufliche Arbeitsmärkte". In: WSI-Mitteilungen 67 (1), pp. 5-13.

Bowles, Jeremy (2014): "The computerisation of European jobs - who will win and who will lose from the impact of new technology onto old areas of employment?". www.bruegel.org.

Brynjolfsson, Erik; McAfee, Andrew (2014): The Second Machine Age: Work, Progress, and Prosperity in a Time of Brilliant Technologies. New York, London: W. W. Norton \& Co. 
Crawford, Matthew B. (2009): Shop Class as Soulcraft: An Inquiry into the Value of Work. New York: The Penguin Press.

Deloitte (2010): Global Manufacturing Competitiveness Index 2010.

Franz, Christine; Voss-Dahm, Dorothea (2011): Ohne Studium (k)eine Führungsposition? Nach wie vor starke Bedeutung von beruflichen Bildungsabschlüssen bei Führungskräften in der Privatwirtschaft. (Nr. 2011-02) Duisburg, Essen: Institut Arbeit und Qualifikation an der Universität Duisburg-Essen (IAQ-Report).

Frey, Carl Benedict; Osborne, Michael A. (2013): The Future of Employment: How Susceptible are Jobs to Computerisation? (Working Paper) Oxford: Oxford Martin School.

Gorecky, Dominic (2014): "Mensch-Maschine-Interaktion im Industrie 4.0-Zeitalter". In: BauernhansI, Thomas; Hompel, Michael ten; Vogel-Heuse, Birgit (eds.) Industrie 4.0 in Produktion. Automatisierung und Logistik. Anwendung - Technologien - Migration. Wiesbaden: Springer Vieweg, pp. 525-542.

Haasler, Bernd (2004): Hochtechnologie und Handarbeit: Eine Studie zur Facharbeit im Werkzeugbau der Automobilindustrie. Gütersloh: Bertelsmann.

Hartmann, Ernst A.; Bovenschulte, Marc (2013): "Skills Needs Analysis for "Industry 4.0". Based on Roadmaps for Smart Systems". In: SKOLKOVO, ILO (eds.) Moscow: Moscow School of Management, pp. 24-36.

Harzing, Anne-Will; Ruysseveldt, Joris van (eds.) (2005): International Human Resource Management. London, Thousand Oaks: Sage.

Hausmann, Ricardo; Hidalgo, César A. (2014): The Atlas of Economic Complexity. Mapping Paths to Prosperity. Cambridge: MIT Press.

Hidalgo, César A.; Hausmann, Ricardo (2009): "The building blocks of economic complexity". In: PNAS - Proceedings of the National Academy of Sciences of the United States of America. 106 (26), pp. 10570-10575.

Hirsch-Kreinsen, Hartmut (2014a): "Welche Auswirkungen hat "Industrie 4.0" auf die Arbeitswelt?". In: WISO direkt (December), pp. 1-4.

Hirsch-Kreinsen, Hartmut; Ittermann, Peter; Niehaus, Jonathan (2015): Digitalisierung industrieller Arbeit. Die Vision Industrie 4.0 und ihre sozialen Herausforderungen. Berlin: Edition Sigma.

Hirsch-Kreinsen, Hartmut (2014b): Wandel von Produktionsarbeit - "Industry 4.0" (Nr. 38/2014) Dortmund: TU Dortmund (Soziologisches Arbeitspapier).

Kädtler, Jürgen; Sperling, Hans Joachim; Wittke, Volker; et al. (2013): Mitbestimmte Innovationsarbeit. Konstellationen, Spielregeln und Partizipationspraktiken. Berlin: Edition Sigma.

Kagermann, Henning; Wahlster, Wolfgang; Helbig, Johannes (2013): Umsetzungsempfehlungen für das Zukunftsprojekt Industrie 4.0. Abschlussbericht des Arbeitskreises Industrie 4.0. Frankfurt/M.: Plattform 4.0.

Klein, Birgit; Menez, Raphael; Oestreicher, Elke; et al. (2015): Chancen und Risiken mobiler und digitaler Kommunikation in der Arbeitswelt. Doppelgutachten für das Büro für Technikfolgenabschätzung beim Deutschen Bundestag (TAB) für die Branchen IKT-Dienstleistung und Automobilproduktion. Stuttgart: Universität Hohenheim.

Li, Fang; Bayrak, Gülden; Kernschmidt, Konstantin; et al. (2012): "Specification of the Requirements to Support Information Technology-Cycles in the Machine and Plant Manufacturing Industry". In: IFAC Symposium on Information Control Problems in Manufacturing (INCOM). Bucharest, pp. 1077-1082. 
Lorenz, Edward; Valeyre, Antoine (2005): “Organisational Innovation, Human Resource Management and Labour Market Structure: A Comparison of the EU-15”. In: The Journal of Industrial Relations 47 (4), pp. 424-442.

Lüder, Arndt (2014): Integration des Menschen in Szenarien der Industrie 4.0. In: Bauernhansl, Thomas; Hampel, Michael ten; Vogel-Heusee, Birgit. (Hg.): Industrie 4.0 in Produktion, Automatisierung und Logistik. Anwendung, Technologien, Migration. Wiesbaden: Springer Vieweg, pp. 493-507.

Müller, Karlheinz (2012): "Der Produktionstechnologe - ein smarter Innovationsakteur”. In: Pfeiffer, Sabine; Schütt, Petra; Wühr, Daniela (eds.) Smarte Innovation. Ergebnisse und neue Ansätze im Maschinen- und Anlagenbau. Wiesbaden: VS Verlag für Sozialwissenschaften, pp. 285-297.

Neumann, Horst (2014): “Eine große Chance für die Arbeit”. Süddeutsche Zeitung, 6 October, p. 2.

Nida-Rümelin, Julian (2014): Der Akdemisierungswahn. Zur Krise beruflicher und akademischer Bildung. Hamburg: Edition Körber-Stiftung.

Pfeiffer, Sabine (2014): "Erfahrungswissen, oder: Von der Bedeutung des sinnlichen Lernens in der "Wissensgesellschaft"'. In: Schröter, Welf (ed.) Identität in der Virtualität. Einblicke in neue Arbeitswelten und "Industrie 4.0". Mössingen: Talheimer, pp. 188-195.

Pfeiffer, Sabine (2015a): "Industrie 4.0 - Phänomen digitalen Despotismus? Ursprung, Akteure und Intentionen eines vermeintlich deutschen Technikdiskurses”. In: Mittelweg 36. Themenheft Arbeit und Technik, pp. (publication pending).

Pfeiffer, Sabine (2015b): "Industrie 4.0 und die Digitalisierung der Produktion - Hype oder Megatrend?”. In: Aus Politik und Zeitgeschichte 65 (31/32), pp. 6-12. www.bpb.de/apuz/209955/industrie-4-0-und-die-digitalisierung-der-produktion.

Pfeiffer, Sabine (2010a): “Technisierung von Arbeit”. In: Böhle, Fritz; Voß, Günter G.; Wachtler, Günther (eds.) Handbuch Arbeitssoziologie. Wiesbaden: VS Verlag für Sozialwissenschaften, pp. 231-261.

Pfeiffer, Sabine (2010b): "Wissenschaftliches Wissen und Erfahrungswissen - und ihre Bedeutung in innovativen Unternehmen". In: IG Metall Vorstand (ed.) Akademisierung von Betrieben Facharbeiter/-innen ein Auslaufmodell? Dokumentation. Frankfurt/M., Dortmund, pp. 87-106.

Pfeiffer, Sabine (2007): Montage und Erfahrung: Warum Ganzheitliche Produktionssysteme menschliches Arbeitsvermögen brauchen. Munich, Mering: Hampp.

Pfeiffer, Sabine (2004): Arbeitsvermögen. Ein Schlüssel zur Analyse (reflexiver) Informatisierung. Wiesbaden: VS Verlag für Sozialwissenschaften.

Pfeiffer, Sabine; Schmauch, Eberhard (2010): "Work Based Usability: ERP-Systeme und Arbeitsrealität". In: MQ Management und Qualität (3), pp. 8-10.

Pfeiffer, Sabine; Schütt, Petra; Ritter, Tobias (2014): “Organisationales Arbeitsvermögen. Eine wichtige Dimension von Beschäftigungsfähigkeit und Bedingung für eine nachhaltige Arbeitsmarktintegration." In: Löw, Martina (ed.) Vielfalt und Zusammenhalt. Verhandlungen des 36. Kongresses der Deutschen Gesellschaft für Soziologie in Bochum und Dortmund 2012. Frankfurt/M., New York: Campus, CD accompanying book.

Pfeiffer, Sabine; Schütt, Petra; Wühr, Daniela (eds.) (2012): Smarte Innovation. Ergebnisse und neue Ansätze im Maschinen-und Anlagenbau. Wiesbaden: VS Verlag für Sozialwissenschaften. 
Pfeiffer, Sabine; Suphan, Anne (2015): Der AV-Index. Lebendiges Arbeitsvermögen und Erfahrung als Ressourcen auf dem Weg zu Industrie 4.0 (Working Paper 2015 \#1, 13 April 2015). Stuttgart: Universität Hohenheim. www.sabine-pfeiffer.de/files/downloads/2015-Pfeiffer-Suphan-draft.pdf.

Picot, Arnold; Neuburger, Rahild (2014): Arbeit in der digitalen Welt. Zusammenfassung der Ergebnisse der AG 1-Projektgruppe anlässlich der IT-Gipfelprozesse 2013 und 2014. Munich: Münchner Kreis.

Pistono, Frederico (2014): Robots Will Steal Your Job But That's Ok. How To Survive the Economic Collapse and be Happy. Los Angeles: Federico Pistono.

Rohrbach-Schmidt, Daniela; Hall, Anja (2013): BIBB/BAuA-Erwerbstätigenbefragung 2012. Version 3.0. (BIBB-FDZ Daten und Methodenberichte Nr. 1/2013) Bonn: Bundesinstitut für Berufsbildung FDZ.

Rüßmann, Michael; Lorenz, Markus; Gerbert, Philipp; et al. (2015): Industry 4.0. The Future of Productivity and Growth in Manufacturing Industries. Boston Consulting Group.

Ryan, Paul; Wagner, Karin; Teuber, Silvia; et al. (2011): Finanzielle Aspekte der betrieblichen Ausbildung in Deutschland, Großbritannien und der Schweiz. Düsseldorf: Hans Böckler Stiftung (working paper).

Schlund, Sebastian; Hämmerle, Moritz; Strölin, Tobias (2014): Industrie 4.0 - Eine Revolution in der Arbeitsgestaltung. Wie Automatisierung und Digitalisierung unsere Produktion verändern werden. Ulm, Stuttgart: Ingenics und FhG IAO.

Schulze, Hartmut (2000): "Erfahrungsgeleitete Arbeit als Leitbild für die Entwicklung und Gestaltung von Produktionssystemen in der industriellen Fertigung". (Dissertation) Hamburg: Universität Hamburg.

Schumann, Michael; Baethge-Kinsky, Volker; Kuhlmann, Martin; et al. (1994): Trendreport Rationalisierung. Berlin: Edition Sigma.

Sennett, Richard (2009): The Craftsman. London, New York: Penguin Sigma.

Spath, Dieter (ed.) (2013): Produktionsarbeit der Zukunft - Industrie 4.0. Stuttgart: Fraunhofer IAO.

Spitz-Oener, Alexandra (2007): The Returns to Pencil Use Revisited. Bonn: IZA (Forschungsinstitut zur Zukunft der Arbeit) (IZA Discussion Paper).

Tiemann, Michael (2014): Homogenität von Berufen. Arbeit und Beruf im Wandel - Ein Blick auf de gesellschaftliche Differenzierung. Bonn: Bundesinstitut für Berufsbildung (BIBB) (Berichte zur beruflichen Bildung).

Weiland, Tim (2013): Arbeitsorganisation und Qualifikation in der Industrie 4.0. Ermittlung der Anforderungen an Management, Mitarbeiter und Arbeitsumfeld in der Produktion. Bremen: Grin.

Windelband, Lars; Fenzl, Claudia; Hunecker, Felix; et al. (2010): Qualifikationsanforderungen durch das Internet der Dinge in der Logistik. Bremen: Institut Technik und Bildung (ITB).

Windelband, Lars; Spöttl, Georg (2012): "Diffusion von Technologien in die Facharbeit und deren Konsequenzen für die Qualifizierung am Beispiel des “Internet der Dinge"”. In: Faßhauer, Uwe; Fürstenau, Bärbel; Wuttke, Eveline+ (eds.) Berufs- und wirtschaftspädagogische Analysen aktuelle Forschungen zur beruflichen Bildung. Opladen, Berlin, Toronto: Budrich, pp. 205-219.

Wühr, Daniela; Pfeiffer, Sabine; Schütt, Petra; et al. (2012): "Innovation im Maschinenbau entlang des Produktlebenszyklus (PLC)”. In: Pfeiffer, Sabine; Schütt, Petra; Wühr, Daniel (eds.) Smarte Innovation. Ergebnisse und neue Ansätze im Maschinen- und Anlagenbau. Wiesbaden: VS Verlag für Sozialwissenschaften, pp. 75-97. 


\section{Previously published manu:scripts}

ITA-01-01 Gunther Tichy, Walter Peissl (12/2001): Beeinträchtigung der Privatsphäre in der Informationsgesellschaft.

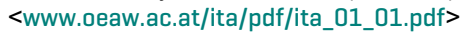

ITA-01-02 Georg Aichholzer (12/2001): Delphi Austria: An Example of Tailoring Foresight to the Needs of a Small Country. <www.oeaw.ac.at/ita/pdf/ita_01_02.pdf>

ITA-01-03 Helge Torgersen, Jürgen Hampel (12/2001): The Gate-Resonance Model: The Interface of Policy, Media and the Public in Technology Conflicts. <www.oeaw.ac.at/ita/pdf/ita_01_03.pdf>

ITA-02-01 Georg Aichholzer (1/2002): Das ExpertInnen-Delphi: Methodische Grundlagen und Anwendungsfeld "Technology Foresight". <www.oeaw.ac.at/ita/pdf/ita_02_01.pdf>

ITA-02-02 Walter Peissl (1/2002): Surveillance and Security - A Dodgy Relationship. $<$ www.oeaw.ac.at/ita/pdf/ita_02_02.pdf>

ITA-02-03 Gunther Tichy (2/2002): Informationsgesellschaft und flexiblere Arbeitsmärkte. <www.oeaw.ac.at/ita/pdf/ita_02_03.pdf>

ITA-02-04 Andreas Diekmann (6/2002): Diagnose von Fehlerquellen und methodische Qualität in der sozialwissenschaftlichen Forschung. <www.oeaw.ac.at/ita/pdf/ita_02_04.pdf>

ITA-02-05 Gunther Tichy (10/2002): Over-optimism Among Experts in Assessment and Foresight. $<w w w . o e a w . a c . a t /$ ita/pdf/ita_02_05.pdf>

ITA-02-06 Hilmar Westholm (12/2002): Mit eDemocracy zu deliberativer Politik? Zur Praxis und Anschlussfähigkeit eines neuen Mediums. <www.oeaw.ac.at/ita/pdf/ita_02_06.pdf>

ITA-03-01 Jörg Flecker und Sabine Kirschenhofer (01/2003): IT verleiht Flügel? Aktuelle Tendenzen der räumlichen Verlagerung von Arbeit. <www.oeaw.ac.at/ita/pdf/ita_03_01.pdf>

ITA-03-02 Gunther Tichy (11/2003): Die Risikogesellschaft - Ein vernachlässigtes Konzept in der europäischen Stagnationsdiskussion. <www.oeaw.ac.at/ita/pdf/ita_03_02.pdf>

ITA-03-03 Michael Nentwich (11/2003): Neue Kommunikationstechnologien und Wissenschaft - Veränderungspotentiale und Handlungsoptionen auf dem Weg zur Cyber-Wissenschaft. <www.oeaw.ac.at/ita/pdf/ita_03_03.pdf>

ITA-04-01 Gerd Schienstock (1/2004): Finnland auf dem Weg zur Wissensökonomie - Von Pfadabhängigkeit zu Pfadentwicklung. <www.oeaw.ac.at/ita/pdf/ita_04_01.pdf>

ITA-04-02 Gunther Tichy (6/2004): Technikfolgen-Abschätzung: Entscheidungshilfe in einer komplexen Welt. <www.oeaw.ac.at/ita/pdf/ita_04_02.pdf>

ITA-04-03 Johannes M. Bauer (11/2004): Governing the Networks of the Information Society - Prospects and limits of policy in a complex technical system. <www.oeaw.ac.at/ita/pdf/ita_04_03.pdf>

ITA-04-04 Ronald Leenes (12/2004): Local e-Government in the Netherlands: From Ambitious Policy Goals to Harsh Reality. <www.oeaw.ac.at/ita/pdf/ita_04_04.pdf>

ITA-05-01 Andreas Krisch (1/2005): Die Veröffentlichung des Privaten - Mit intelligenten Etiketten vom grundsätzlichen Schutz der Privatsphäre zum Selbstschutz-Prinzip. <www.oeaw.ac.at/ita/pdf/ita_05_01.pdf>

ITA-05-02 Petra Grabner (12/2005): Ein Subsidiaritätstest - Die Errichtung gentechnikfreier Regionen in Österreich zwischen Anspruch und Wirklichkeit. <epub.oeaw.ac.at/ita/ita-manuscript/ita_05_02.pdf>

ITA-05-03 Eva Buchinger (12/2005): Innovationspolitik aus systemtheoretischer Sicht - Ein zyklisches Modell der politischen Steuerung technologischer Innovation. <www.oeaw.ac.at/ita/pdf/ita_05_03.pdf>

ITA-06-01 Michael Latzer (6/2006): Medien- und Telekommunikationspolitik: Unordnung durch Konvergenz - Ordnung durch Mediamatikpolitik. <epub.oeaw.ac.at/ita/ita-manuscript/ita_06_01.pdf>

ITA-06-02 Natascha Just, Michael Latzer, Florian Saurwein (9/2006): Communications Governance: Entscheidungshilfe für die Wahl des Regulierungsarrangements am Beispiel Spam. <epub.oeaw.ac.at/ita/ita-manuscript/ita_06_02.pdf>

ITA-06-03 Veronika Gaube, Helmut Haberl (10/2006): Sozial-ökologische Konzepte, Modelle und Indikatoren nachhaltiger Entwicklung: Trends im Ressourcenverbrauch in Österreich. <epub.oeaw.ac.at/ita/ita-manuscript/ita_06_03.pdf>

ITA-06-04 Maximilian Fochler, Annina Müller (11/2006): Vom Defizit zum Dialog? Zum Verhältnis von Wissenschaft und Öffentlichkeit in der europäischen und österreichischen Forschungspolitik. <epub.oeaw.ac.at/ita/ita-manuscript/ita_06_04.pdf>

ITA-06-05 Holger Floeting (11/2006): Sicherheitstechnologien und neue urbane Sicherheitsregimes <epub.oeaw.ac.at/ita/ita-manuscript/ita_06_05.pdf>

ITA-06-06 Armin Spök (12/2006): From Farming to „Pharming” - Risks and Policy Challenges of Third Generation GM Crops. <epub.oeaw.ac.at/ita/ita-manuscript/ita_06_06.pdf>

ITA-07-01 Volker Stelzer, Christine Rösch, Konrad Raab (3/2007): Ein integratives Konzept zur Messung von Nachhaltigkeit - das Beispiel Energiegewinnung aus Grünland. <epub.oeaw.ac.at/ita/ita-manuscript/ita_07_01.pdf>

ITA-07-02 Elisabeth Katzlinger (3/2007): Big Brother beim Lernen: Privatsphäre und Datenschutz in Lernplattformen. <epub.oeaw.ac.at/ita/ita-manuscript/ita_07_02.pdf>

ITA-07-03 Astrid Engel, Martina Erlemann (4/2007): Kartierte Risikokonflikte als Instrument reflexiver Wissenspolitik <epub.oeaw.ac.at/ita/ita-manuscript/ita_07_03.pdf>

ITA-07-04 Peter Parycek (5/2007): Gläserne Bürger - transparenter Staat? Risiken und Reformpotenziale des öffentlichen Sektors in der Wissensgesellschaft. <epub.oeaw.ac.at/ita/ita-manuscript/ita_07_04.pdf>

ITA-07-05 Helge Torgersen (7/2007): Sicherheitsansprüche an neue Technologien - das Beispiel Nanotechnologie. <epub.oeaw.ac.at/ita/ita-manuscript/ita_07_05.pdf>

ITA-07-06 Karen Kastenhofer (9/2007): Zwischen „schwacher“ und „starker“ Interdisziplinarität. Die Notwendigkeit der Balance epistemischer Kulturen in der Sicherheitsforschung zu neuen Technologien. <epub.oeaw.ac.at/ita/ita-manuscript/ita_07_06.pdf> 
ITA-07-07 Ralf Lindner, Michael Friedewald (9/2007): Gesellschaftliche Herausforderungen durch „intelligente Umgebungen. Dunkle Szenarien als TA-Werkzeug. <epub.oeaw.ac.at/ita/ita-manuscript/ita_07_07.pdf>

ITA-07-08 Alfons Bora (11/2007): Die disziplinären Grundlagen der Wissenschaft. <epub.oeaw.ac.at/ita/ita-manuscript/ita_07_08.pdf>

ITA-08-01 Alexander Degelsegger (5/2008): „Frames“ in sozialwissenschaftlichen Theorieansätzen. Ein Vergleich aus der Perspektive der Technikforschung. <epub.oeaw.ac.at/ita/ita-manuscript/ita_08_01.pdf>

ITA-08-02 Jens Hoff (11/2008): Can The Internet Swing The Vote? Results from a study of the 2007 Danish parliamentary election. <epub.oeaw.ac.at/ita/ita-manuscript/ita_08_02.pdf>

ITA-09-01 Georg Aichholzer, Doris Allhutter (2/2009): e-Participation in Austria: Trends and Public Policies. <epub.oeaw.ac.at/ita/ita-manuscript/ita_09_01.pdf>

ITA-09-02 Michael Nentwich (11/2009): Cyberscience 2.0 oder 1.2? Das Web 2.0 und die Wissenschaft. <epub.oeaw.ac.at/ita/ita-manuscript/ita_09_02.pdf>

ITA-09-03 Hilmar Westholm (12/2009): Wandel der Formen politischer Partizipation und der Beitrag des Internet. Schlussfolgerungen aus Bevölkerungsbefragungen in Deutschland. <epub.oeaw.ac.at/ita/ita-manuscript/ita_09_03.pdf>

ITA-10-01 Iris Eisenberger (12/2010): Kleine Teile, große Wirkung? Nanotechnologieregulierung in der Europäischen Union. <epub.oeaw.ac.at/ita/ita-manuscript/ita_10_01.pdf>

ITA-10-02 Alexander Degelsegger and Helge Torgersen (12/2010): Instructions for being unhappy with PTA. The impact on PTA of Austrian technology policy experts' conceptualisation of the public. <epub.oeaw.ac.at/ita/ita-manuscript/ita_10_02.pdf>

ITA-10-03 Ernest Braun (12/2010): The Changing Role of Technology in Society. <epub.oeaw.ac.at/ita/ita-manuscript/ita_10_03.pdf>

ITA-10-04 Fritz Betz (12/2010): E-Partizipation und die Grenzen der Diskursethik. <epub.oeaw.ac.at/ita/ita-manuscript/ita_10_04.pdf>

ITA-11-01 Peter Parycek, Judith Schoßböck (1/2011): Transparency for Common Good. Offener Zugang zu Information im Kontext gesellschaftlicher und strategischer Spannungsfelder. <epub.oeaw.ac.at/ita/ita-manuscript/ita_11_01.pdf>

ITA-11-02 Georg Aichholzer und Doris Allhutter (6/2011): Online forms of political participation and their impact on democracy. <epub.oeaw.ac.at/ita/ita-manuscript/ita_11_02.pdf>

ITA-11-03 Mahshid Sotoudeh, Walter PeissI, Niklas Gudowsky, Anders Jacobi (12/2011): Long-term planning for sustainable development. CIVISTI method for futures studies with strong participative elements. <epub.oeaw.ac.at/ita/ita-manuscript/ita_11_03.pdf>

ITA-12-01 Xiao Ming (1/2012): e-Participation in Government Decision-Making in China. Reflections on the Experience of Guangdong Province. <epub.oeaw.ac.at/ita/ita-manuscript/ita_12_01.pdf>

ITA-12-02 Stephan Bröchler, Georg Aichholzer, Petra Schaper-Rinkel (Hrsg.) (9/2012): Theorie und Praxis von Technology Governance. <epub.oeaw.ac.at/ita/ita-manuscript/ita_12_02_Sondernummer.pdf>

ITA-12-03 Iris Eisenberger (10/2012): EU-Verhaltenskodex Nanotechnologie: Rechtsstaatliche und demokratische Aspekte. <epub.oeaw.ac.at/ita/ita-manuscript/ita_12_03.pdf>

ITA-12-04 Julia Haslinger, Christiane Hauser, Peter Hocke, Ulrich Fiedeler (10/2012): Ein Teilerfolg der Nanowissenschaften? Eine Inhaltsanalyse zur Nanoberichterstattung in repräsentativen Medien Österreichs, Deutschlands und der Schweiz. <epub.oeaw.ac.at/ita/ita-manuscript/ita_12_04.pdf>

ITA-13-01 Helge Torgersen, Alexander Bogner, Karen Kastenhofer (10/2013): The Power of Framing in Technology Governance: The Case of Biotechnologies. <epub.oeaw.ac.at/ita/ita-manuscript/ita_13_01.pdf>

ITA-13-02 Astrid Mager (11/2013): In search of ideology. Socio-cultural dimensions of Google and alternative search engines. <epub.oeaw.ac.at/ita/ita-manuscript/ita_13_02.pdf>

ITA-13-03 Petra Wächter (12/2013): Aspekte einer nachhaltigen Energiezukunft. <epub.oeaw.ac.at/ita/ita-manuscript/ita_13_03.pdf>

ITA-14-01 Renate Mayntz (8/2014): Technikfolgenabschätzung - Herausforderungen und Grenzen. <epub.oeaw.ac.at/ita/ita-manuscript/ita_14_01.pdf>

ITA-14-02 Michael Narodoslawsky (11/2014): Utilising Bio-resources: Rational Strategies for a Sustainable Bio-economy. <epub.oeaw.ac.at/ita/ita-manuscript/ita_14_02.pdf>

ITA-14-03 Petra Wächter (12/2014): Ökonomik in der Technikfolgenabschätzung - eine Bestandsaufnahme. <epub.oeaw.ac.at/ita/ita-manuscript/ita_14_03.pdf>

ITA-15-01 Reinhard Grünwald (5/2015): Stromnetze: Bedarf, Technik, Folgen. <epub.oeaw.ac.at/ita/ita-manuscript/ita_15_01.pdf>

ITA-15-02 Christine Chaloupka, Robert Kölbl, Wolfgang Loibl, Romain Molitor, Michael Nentwich, Stefanie Peer, Ralf Risser, Gerd Sammer, Bettina Schützhofer, Claus Seibt (6/2015): Nachhaltige Mobilität aus sozioökonomischer Perspektive - Diskussionspapier der Arbeitsgruppe „Sozioökonomische Aspekte“ der ÖAW-Kommission „Nachhaltige Mobilität“. <epub.oeaw.ac.at/ita/ita-manuscript/ita_15_02.pdf>

ITA-15-03 Sabine Pfeiffer (10/2015): Auswirkungen von Industrie 4.0 auf Aus- und Weiterbildung. <epub.oeaw.ac.at/ita/ita-manuscript/ita_15_03.pdf>

ITA-15-04 Sabine Pfeiffer (11/2015): Effects of Industry 4.0 on vocational education and training <epub.oeaw.ac.at/ita/ita-manuscript/ita_15_04.pdf> 